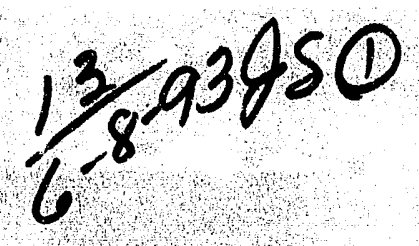

$\frac{\text { PNL }-8622}{\mathrm{UC}-313}$

Inert Electrodes Program

\title{
Fabrication of Advanced Design (Grooved) Cermet Anodes
}

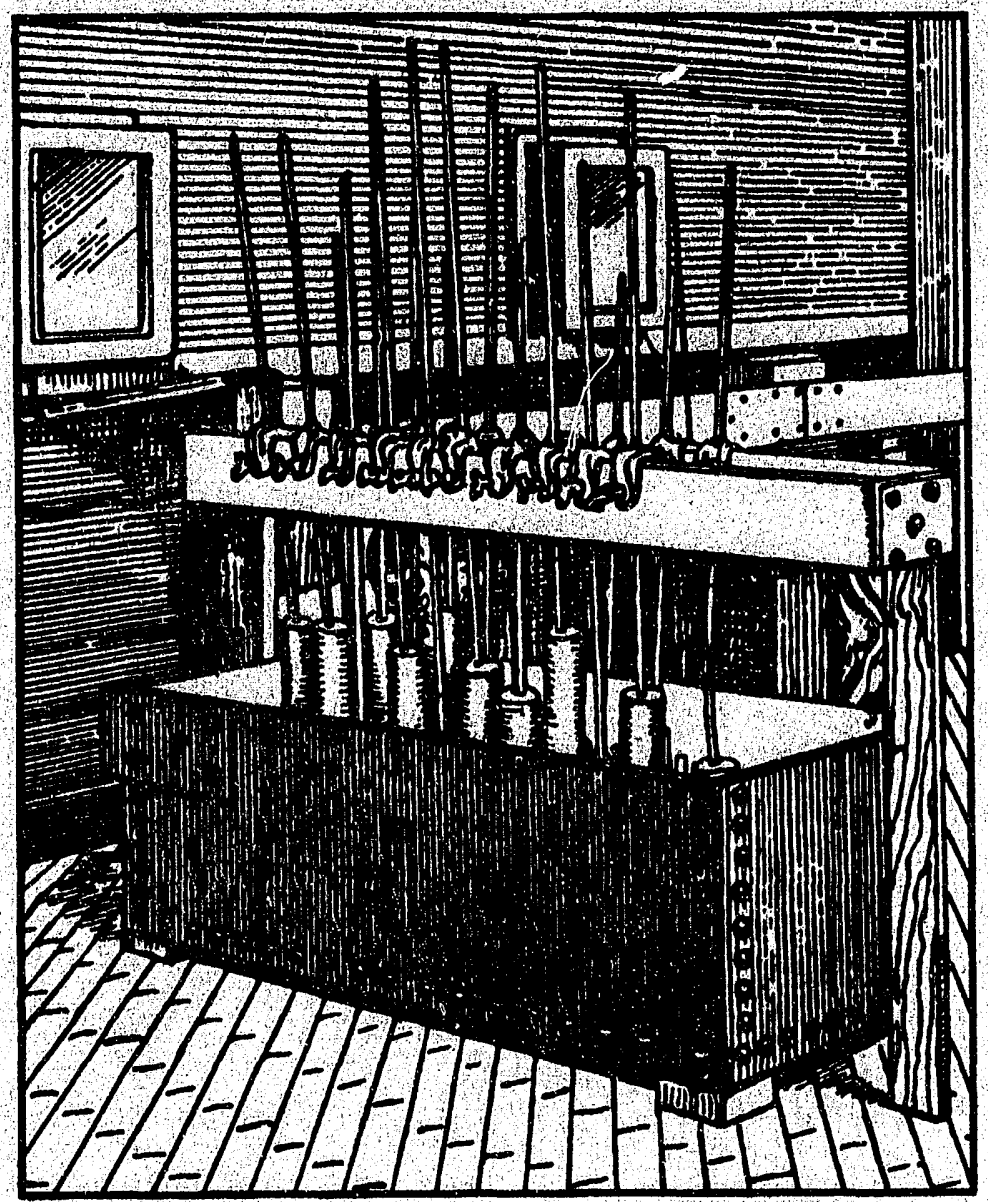

May 1993

Work Supported by the U.S. Department of Energy under Contract DE-AC06-76RLO 1830

Pacific Northwest Laboratory

Operated for the U.S. Department of Energy

by Battelle Memorial Institute 


\section{DISCLAIMER}

This report was prepared as an account of work sponsored by an agency of the United States Government. Neither the United States Government nor any agency thereof, nor Battelle Memorial Institute, nor any of their employees, makes any warranty, expressed or implied, or assumes any legal liability or responsibility for the accuracy, completeness, or usefulness of any information, apparatus, product, or process disclosed, or represents that its use would not infringe privately owned rights. Reference herein to any specific commercial product, process, or service by trade name, trademark, manufacturer, or otherwise does not necessarily constitute or imply its endorsement, recommendation, or favoring by the United States Government or any agency thereof, or Battelle Memorial Institute. The views and opinions of authors expressed herein do not necessarily state or reflect those of the United States Government or any agency thereof.

\section{PACIFIC NORTHWEST LABORATORY operated by}

BATTELLE MEMORIAL INSSTITUTE for the

UNITED STATES DEPARTMENT OF ENERGY under Contract DE-AC06-\$6RLO 1830

Printed in the United States dif America

Available to DOE and DOE contrictors from the

Office of Scientific and Technical Information, P.O. Box 62, Oak Ridge, IN 37831; prices available from (615) 576-8401. FTS 626-8401.

Available to the public from the National Teclinical Information Service, U.S. Department of Commerce, 5285 Port Royal Rd., Springfield, VA 22161. 
Inert Electrodes Program

\section{Fabrication of Advanced Design (Grooved) Cermet Anodes}

C. F. Windisch Jr.

F. R. Huettig ${ }^{(a)}$

May 1993

Prepared for

The U.S. Department of Energy

under Contract DE-AC06-76RLO 1830

Pacific Northwest Laboratory

Richland, Washington 99352

\section{MASTER}

(a) Ceramic Magnetics, Inc., 16 Law Drive, Fairfield, NJ 07004

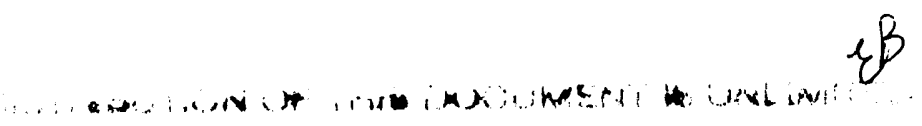




\section{Acknowledgments}

The authors acknowledge the staff at Ceramic Magnetics, Inc. (CMI) who helped in the fabrication of the cermet anodes and the staff at the Pacific Northwest Laboratory (PNL) who participated in the post-fabrication analysis. We acknowledge the contributions of L. VanDillan, CMI, R. Haber, Rutgers University, and E. Krug, Certech, Inc., in key aspects of the fabrication work; the technical comments provided by C. H. Henager Jr., PNL; and the editorial assistance given by D. K. Hilliard, PNL. We are also grateful for the programmatic support provided by M. J. McMonigle and the Office of Industrial Processes (OIP), U.S. Department of Energy (DOE), Washington, D.C. 


\section{Summary}

Attempts were made to fabricate full-size anodes with advanced, or grooved, design using isostatic pressing and slip casting. Anode material was also made using injection molding. Of the three approaches, isostatic pressing produced an anode with dimensions nearest to the target specifications and without serious macroscopic flaws. For this reason, this approach is considered the most promising as a near-term solution for making advanced anodes for aluminum smelting. If this approach is selected, however, significant work still remains to optimize the physical properties and microstructure of the anode, both of which were found to be significantly different from that of anodes previously made at the Pacific Northwest Laboratory (PNL) ${ }^{(a)}$ and Alcoa Laboratories. It is strongly recommended that these dissimilarities be remedied before conducting any large-scale reduction cell testing of the material.

Injection molding and slip casting yielded anode materials with serious deficiencies, including cracks and holes. While these problems might be corrected with additional development work, it seems unlikely that workable solutions could be found in the short run.

Interestingly, the injection molding approach gave cermet material with the best intrinsic microstructure, i.e., the microstructure of the material between macroscopic flaws was very similar to that of anodes previously made at PNL. The reason for the similarity is not certain but may have to do with the amount of residual binder in the material prior to sintering.

(a) Operated for the U.S. Department of Energy by Battelle Memorial Institute under Contract DE-AC06-76RLO 1830. 


\section{Contents}

Acknowledgments $\ldots \ldots \ldots \ldots \ldots \ldots \ldots \ldots \ldots \ldots \ldots$ ii

Summary $\ldots \ldots \ldots \ldots \ldots \ldots \ldots \ldots \ldots \ldots \ldots \ldots \ldots \ldots$

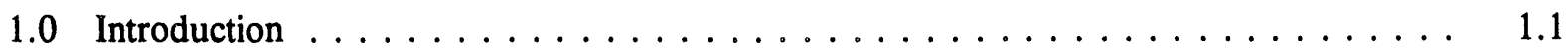

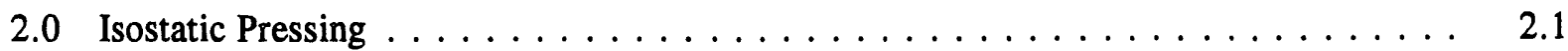

2.1 Description of Fabrication Approach $\ldots \ldots \ldots \ldots \ldots \ldots \ldots \ldots$

2.2 Observations During Fabrication $\ldots \ldots \ldots \ldots \ldots \ldots \ldots \ldots \ldots \ldots$

2.3 Post-Fabrication Analysis $\ldots \ldots \ldots \ldots \ldots \ldots \ldots \ldots \ldots \ldots \ldots$

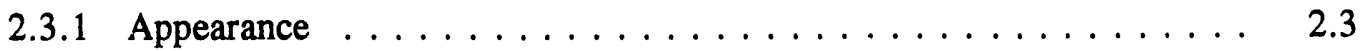

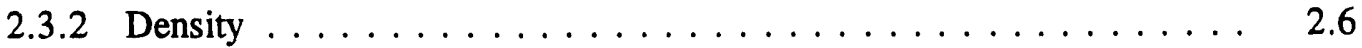

2.3.3 Microstructure and Composition $\ldots \ldots \ldots \ldots \ldots \ldots$

2.4 Conclusions $\ldots \ldots \ldots \ldots \ldots \ldots \ldots \ldots \ldots \ldots \ldots \ldots \ldots \ldots$

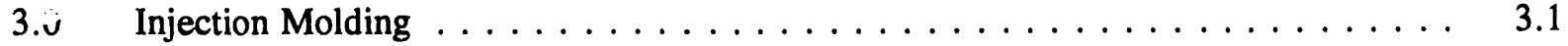

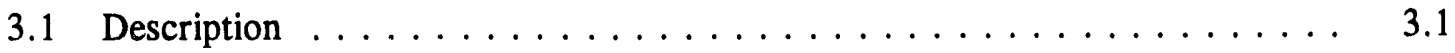

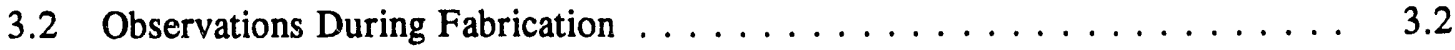

3.3 Post-Fabrication Analysis $\ldots \ldots \ldots \ldots \ldots \ldots \ldots \ldots \ldots \ldots \ldots \ldots \ldots$

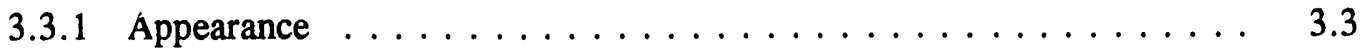

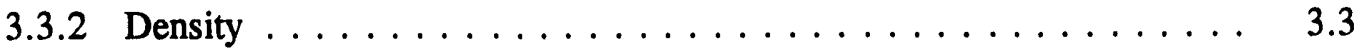

3.3.3 Microstructure and Composition $\ldots \ldots \ldots \ldots \ldots \ldots \ldots \ldots$

3.4 Conclusions $\ldots \ldots \ldots \ldots \ldots \ldots \ldots \ldots \ldots \ldots \ldots \ldots \ldots \ldots \ldots$

$4.0 \quad$ Slip Casting $\ldots \ldots \ldots \ldots \ldots \ldots \ldots \ldots \ldots \ldots \ldots \ldots \ldots \ldots \ldots \ldots$

4.1 Description of Fabrication Approach $\ldots \ldots \ldots \ldots \ldots \ldots \ldots \ldots \ldots$ 
4.2 Observations During Fabrication $\ldots \ldots \ldots \ldots \ldots \ldots \ldots \ldots \ldots \ldots$

4.3 Post-Fabrication Analysis $\ldots \ldots \ldots \ldots \ldots \ldots \ldots \ldots \ldots$

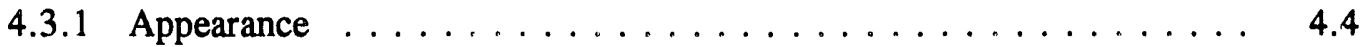

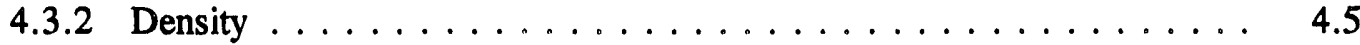

4.3.3 Microstructure and Composition $\ldots \ldots \ldots \ldots \ldots . \ldots \ldots$

4.4 Conclusions $\ldots \ldots \ldots \ldots \ldots \ldots \ldots \ldots \ldots \ldots \ldots \ldots \ldots \ldots$

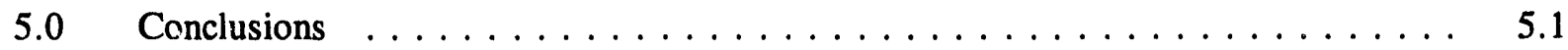

5.1 Overall Comparison of the Approaches $\ldots \ldots \ldots \ldots \ldots \ldots \ldots \ldots$

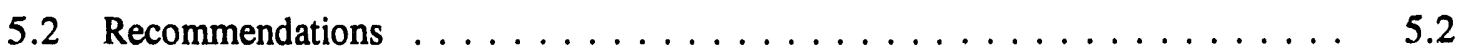

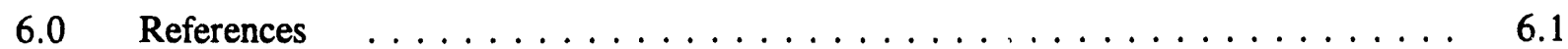




\section{Figures}

1.1 Conceptual Design of a Reduction Cell With Two-Dimensional Array of Grooved Anodes (Side View) . . . . . . . . . . . . . . . . . . . . . . . . . . 1.2

1.2 Conceptual Design of a Reduction Cell With Two-Dimensional Array of Grooved Anodes (Top View) . . . . . . . . . . . . . . . . . . . . . . 1.3

1.3 Key Features of the Advanced Design Anode: a) Top View; and b) Side View . . . $\quad 1.5$

2.1 Views of CM-I: a) Bottom View Showing Grooves; b) Side View Showing Grooves; c) Side View; d) Top View Showing Hole for Connector Rod . . . . . . . 2.4

2.2 Anode CM-II Showing Crust on Top Surface $\ldots \ldots \ldots \ldots \ldots \ldots \ldots \ldots$

$2.3 \quad$ Ultrasonic Scan from Top Surface of CM-I $\ldots \ldots \ldots \ldots \ldots \ldots$

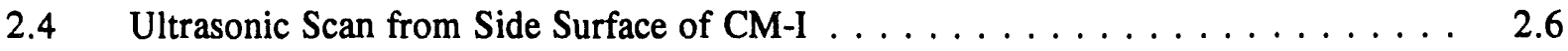

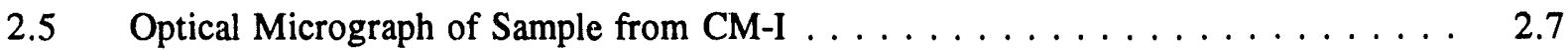

2.6 Optical Micrograph of Sample from CM-I Showing Porous Region Between

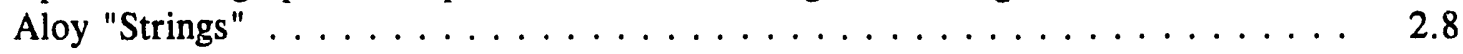

2.7 SEM Micrographs of: a) Sample from CM-I; and b) Sample from PNL Anode $\ldots \quad \ldots .9$

3.1 Views of CM-III: a) Bottom Surface Showing Checkerboard; and b) Top Surface

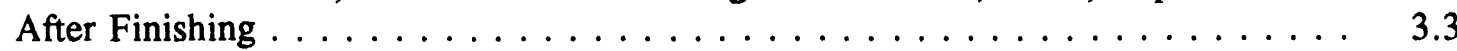

3.2 SEM Micrographs of a) Sample from CM-III; and b) Sample from PNL Anode . . 3.4

3.3 Optical Micrograph of Sample from CM-III Showing Fissures $\ldots \ldots \ldots \ldots \ldots$

4.1 Views of CM-IV: a) Bottom Surface Showing Grooves; b) Side View Showing Grooves; c) Top View Showing Depression; and d) Close-Up Side View Showing Cracks .............................. 4.5

4.2 Optical Micrograph of Sample from CM-IV Showing Typical Microstructure $\ldots \ldots \quad 4.6$

4.3 Optical Micrograph of Sample from CM-IV Showing Hole $\ldots \ldots \ldots \ldots$. . . . . 4.7 
4.4 SEM Micrographs of: a) Sample from CM-IV; and b) Sample from PNL

Anode

5.1 Comparison of Compositions of the Three Phases in the Cermet Material from Various Anode Sources

\section{Tables}

1.1 Target Dimensions of the Advanced Design Anode $\ldots \ldots \ldots \ldots \ldots \ldots$

$1.2 \quad$ Advanced Design Anodes Fabricated by CMI $\ldots \ldots \ldots \ldots \ldots$

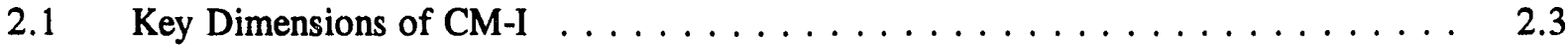

4.1 CMI Casting Attempts $\ldots \ldots \ldots \ldots \ldots \ldots \ldots \ldots \ldots \ldots \ldots \ldots \ldots$

4.2 Key Dimensions of CM-IV $\ldots \ldots \ldots \ldots \ldots \ldots \ldots \ldots \ldots \ldots \ldots$ 


\subsection{Introduction}

Cermet anodes have been under development at the Pacific Northwest Laboratory (PNL) for use as a nonconsumable alternative to carbon anodes in the electrolytic production of aluminum metal. The research at PNL has been funded by the Office of Industrial Processes (OIP) of the U.S. Department of Energy (DOE) since the mid-1980s. In the early 1980s, DOE-OIP funded a similar program at Alcoa Laboratories (Alcoa Center, Pennsylvania). Alcoa first identified a cermet of the type NiO$\mathrm{NiFe}_{2} \mathrm{O}_{4}-\mathrm{Cu}$ as a promising material for a nonconsumable anode and obtained wear ${ }^{(\mathrm{a})}$ rates of about $1.8 \mathrm{~cm} \cdot \mathrm{yr}^{-1}$ in laboratory reduction cells (Weyand et al. 1986). ${ }^{\text {(b) }}$ PNL also obtained good results in laboratory testing on this material with wear rates as low as $0.6 \mathrm{~cm}^{-1} r^{-1}$ (Strachan et al. 1989). Despite the promising laboratory results, however, it was found that the performance of the cermet material was also strongly influenced by cell conditions, especially alumina concentration in the bath (Weyand et al. 1986; Strachan et al. 1988). When alumina concentration dropped significantly below saturation, ${ }^{(\mathfrak{c})}$ wear rates increased. The precise mechanism for the excessive wear at low alumina concentrations is not completely understood but appears to involve dissolution of the oxide phases under these conditions. ${ }^{(d)}$ Periodic excursions in alumina concentration were also believed to be partly responsible for the less-than-optimal performance of the first pilot-scale demonstration of the $\mathrm{NiO}-\mathrm{NiFe}_{2} \mathrm{O}_{4}-\mathrm{Cu}$ material in August 1991 (Windisch et al. 1992a).

A strategy for maintaining alumina concentration as close to saturation as possible is required if the cermet anodes are to be used successfully. One such strategy was proposed by M. J. McMonigle, DOE-OIP, and supported by the modeling studies by Evans $(1990 \mathrm{a} ; 1990 \mathrm{~b})$. The basic idea in this approach is that alumina concentration may be controlled uear saturation by using a particular anode

(a) "Wear" is the common term lised for degradation of the anode and has been primarily associated with dimensional loss. By convention, its units are $\mathrm{cm} \cdot \mathrm{yr}^{-1}$. However, since wear has also been quantified by measurements of anode components that report to the Al metal pad, a more comprehensive definition would seem to require considering all oxidation/dissolution processes occurring at the anode, both within the interior of the cermet and at its surface. This issue is complex and is not discussed further in the text. Refer to previous PNL publications for a more thorough description of anode wear (Strachan et al. 1989; Windisch and Stice 1991; Windisch et al. 1992a). It is also important to note that the wear rates given in the text are extrapolated from short-term tests, assuming linearity.

(b) $\mathrm{T}$, wear rates in this report were calculated from the amount of $\mathrm{Cu}$ lost from the anode. Losses for $\mathrm{Fe}$ and $\mathrm{Ni}$ give even lower wear rates.

(c) The lower limit for alumina concentration that gives acceptable wear rates has not been precisely determined for numerous reasons (Strachan et al. 1989; Windisch et al. 1992b). Consequently, the goal of all testing beyond the bench scale has been to maintain alumina concentration as close as possible to saturation in the bath.

(d) The metallic phase is also affected. Anodes polarized under conditions of varied alumina concentration in the bath showed reaction layers of significant thickness characterized by oxidation of the metallic phase (Tarcy 1986; Strachan et al. 1988; Strachan et al. 1989; Strachan et al. 1990). 
shape and reduction cell design. The new electrode configuration would promote the channelling of bubble flow (from oxygen gas produced at the nonconsumable anodes) in such a way as to facilitate the dissolution of the alumina that is added periodically to the bath. The anode shape that was predicted to give the most effective channeling of the gas had "grooves" on its bottom. Anodes with this shape have been referred to alternately as "grooved anodes" and "anodes with advanced design" or, in some cases, as simply "advanced anodes." Details on how various aspects of the grooved shape would affect bubble flow were the outcome of the studies performed by Evans (1990a; 1990b). A schematic of grooved anodes clustered in a two-dimensional array and an illustration of how this array would be deployed in a reduction cell are shown in Figures 1.1 and 1.2, respectively. ${ }^{(a)}$ The anodes would be completely submerged in the bath and oriented with a sl ight tilt (or with baffles to accomplish the same purpose as discussed below). The mechanical support would be the electrical connector rods, which would be protected from corrosion by the bath with sleeves of ceramic

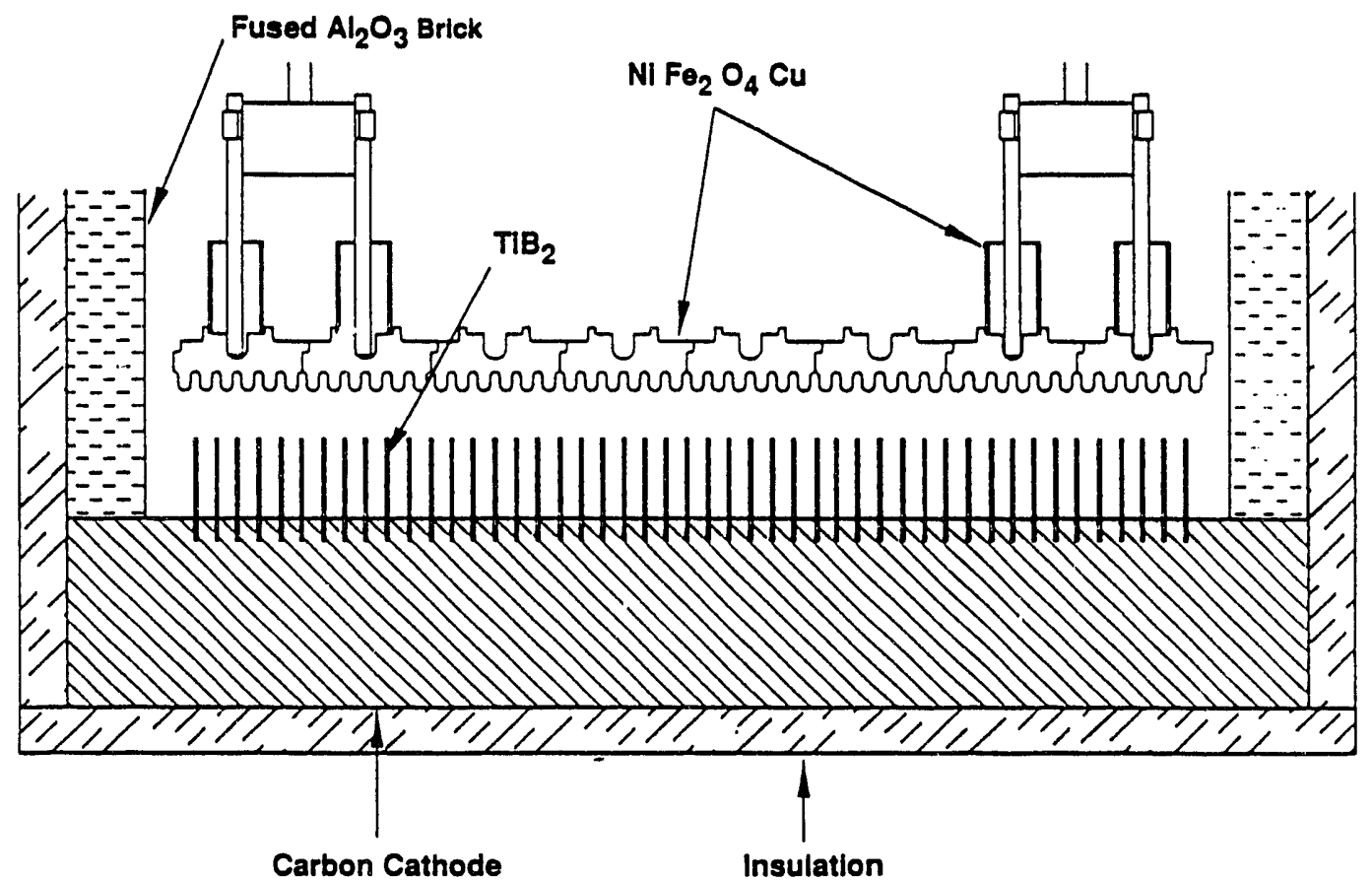

Figure 1.1. Conceptual Design of a Reduction Cell with Two-Dimensional Array of Grooved Anodes (Side View)

(a) The anodes in an advanced reduction cell were conceived to be a two-dimensional array of interlocked modules, each with the design that was evaluated in this study. The modular approach would facilitate handling of the comparatively dense material and, at the same time, afford the advantages of a large anode when assembled in the cell. 


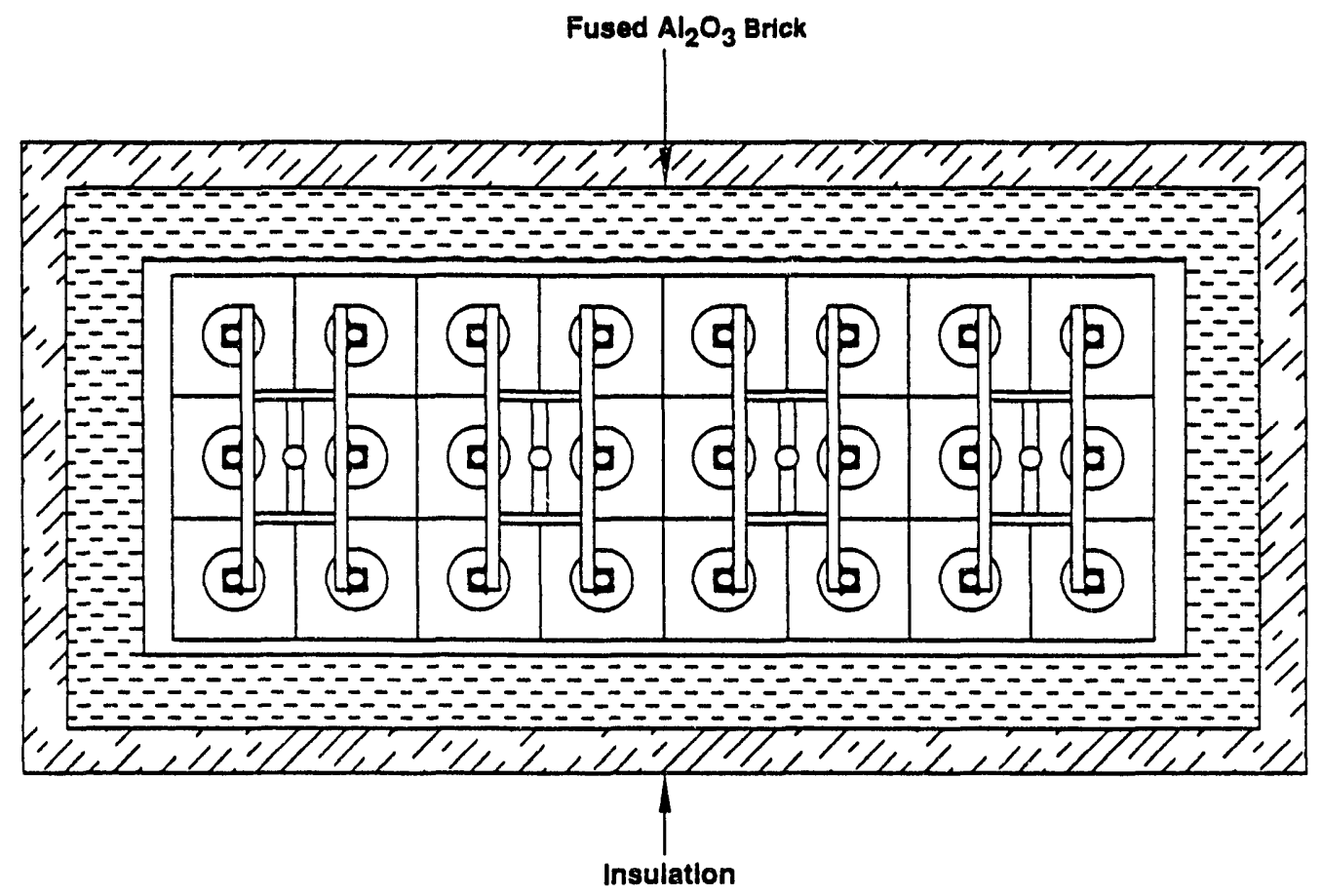

Figure 1.2. Conceptual Design of a Reduction Cell with Two-Dimensional Array of Grooved Anodes (Top View)

material. During operation, the oxygen gas bubbles generated at the anodes would be channeled by the grooves across the tilted bottom surface and up one of the sides of the array. This would create forced currents of bath in the direction of the bubble flow, up the same side of the array and over its top. Alumina that was added to the bath would be forced across the top surface of the array by the bath currents and eventually down into the bulk of the electrolyte and back under the anodes. It was predicted that this type of bath flow would maintain alumina saturation very effectively in the grooved region of the anodes where electrolysis would take place. The flow of bath would also be controlled by the positioning of the $\mathrm{TiB}_{2}$ cathodes that are being developed in conjunction with the cermet anodes. The successful "marriage" of the cermet anodes and $\mathrm{TiB}_{2}$ cathodes has long been regarded as an important step in the evolution of aluminum smelting technology (Billehaug and Oye 1981).

The fabrication of anodes with the advanced design involves numerous challenges in addition to those encountered in scaling up the fabrication of more primitively shaped pieces such as those used in the pilot cell test (Windisch et al. 1992a). An important issue concerning an anode with a complex, grooved, shape is that, to make the fabrication economically attractive, it would have to be manufactured commercially without much machining. The $\mathrm{NiO}-\mathrm{NiFe}_{2} \mathrm{O}_{4}-\mathrm{Cu}$ anodes produced at $\mathrm{PNL}$ and Alcoa laboratories were made primarily by isostatic pressing. Since the fabrication of large ceramic bodies with complex shapes without machining is more easily accomplished using other methods (Segal 1989), it was considered worthwhile to investigate alternative fabrication approaches concurrent with the initial efforts to fabricate advanced anodes. The only drawback to this approach was that many of these alternative methods (none under scaled-up conditions) had never been tried on 
the cermet composition before, so that unqualified success in this first set of fabrication attempts was considered remote. Nevertheless, in a meeting between personnel from DOE-HQ, PNL, and the ferrite industry, held in Fairfield, New Jersey, on June 21, 1991, it was decided to investigate alternative fabrication methods in conjunction with making the first large, grooved anode. It was decided at this meeting that three fabrication approaches should be investigated: 1) isostatic pressing; 2) injection molding; and 3) slip casting. The main objective of the initial study would be to make the best, first attempt to fabricate a large, grooved cermet anode using these three approaches. Any of the approaches could be abandoned, at any stage of development, if shown to be infeasible or unlikely to succeed with the time and resources available. The specified deliverable was one anode made by the method deemed most successful. After fabrication, the anode would be analyzed by PNL staff to determine how close it was to the intended desigit and, in composition and properties, to cermet anodes previously made at PNL. If more than one anode could be made using more than one of the approaches, those anodes would be subjected to analysis at PNL as well. Following this analysis, recommendations would be made concerning future development of the grooved cermet anodes. In particular, the most promising of the three approaches would be identified and steps for future development would be recommended.

On December 21, 1991, Curamic Magnetics, Inc. (CMI) was selected as the vendor to fabricate one cermet anode by any of the three candidate approaches, with an additional anode to be fabricated by another approach if time and resources were available. The method actually chosen for the one anode would be left to the manufacturer, to be decided after preliminary testing of the candidate approaches. However, it was specifically stated that no machining be employed. The work was to be viewed as developmental in nature with manufacturing proceeding on a best-effort basis. Other conditions in the statement of work were that the manufacturer would first submit a detailed engineering drawing of the grooved anode and that this drawing would conform to preliminary sketches provided by PNL staff. Key features of the engineering drawing received from CMI are shown in Figure 1.3 and important dimensions of the anode are summarized in Table 1.1. The powder starting material for the grooved anode was to be provided by PNL via a purchase order to a ferrite powder manufacturer. As it turned out, CMI was the company that manufactured the powder for the pilot cell anodes (Windisch et al. 1992a), so CMI was selected as the vendor to fabricate the powder for the grooved anodes as well. Five-hundred pounds of ceramic powder were prepared by CMI for the advanced design anodes using the same procedure that was used to make the powder for the pilot cell

Table 1.1. Target Dimensions of the Advanced Design Anode

\begin{tabular}{|c|c|c|}
\hline Description & Symbol & Nominal Measurement, in. \\
\hline Top Surface (Square) & TS & $8 \times 8$ \\
\hline Total Height & TH & 4.4 \\
\hline Groove-to-Lip & GL & 1.25 \\
\hline Groove Height (or Depth) & GH & 1.5 \\
\hline Groove Separation & GS & 1.5 \\
\hline Groove Radius (Outside) & GR & 0.5 \\
\hline Overhanging Lip Thickness & LT & 0.75 \\
\hline
\end{tabular}


(a)
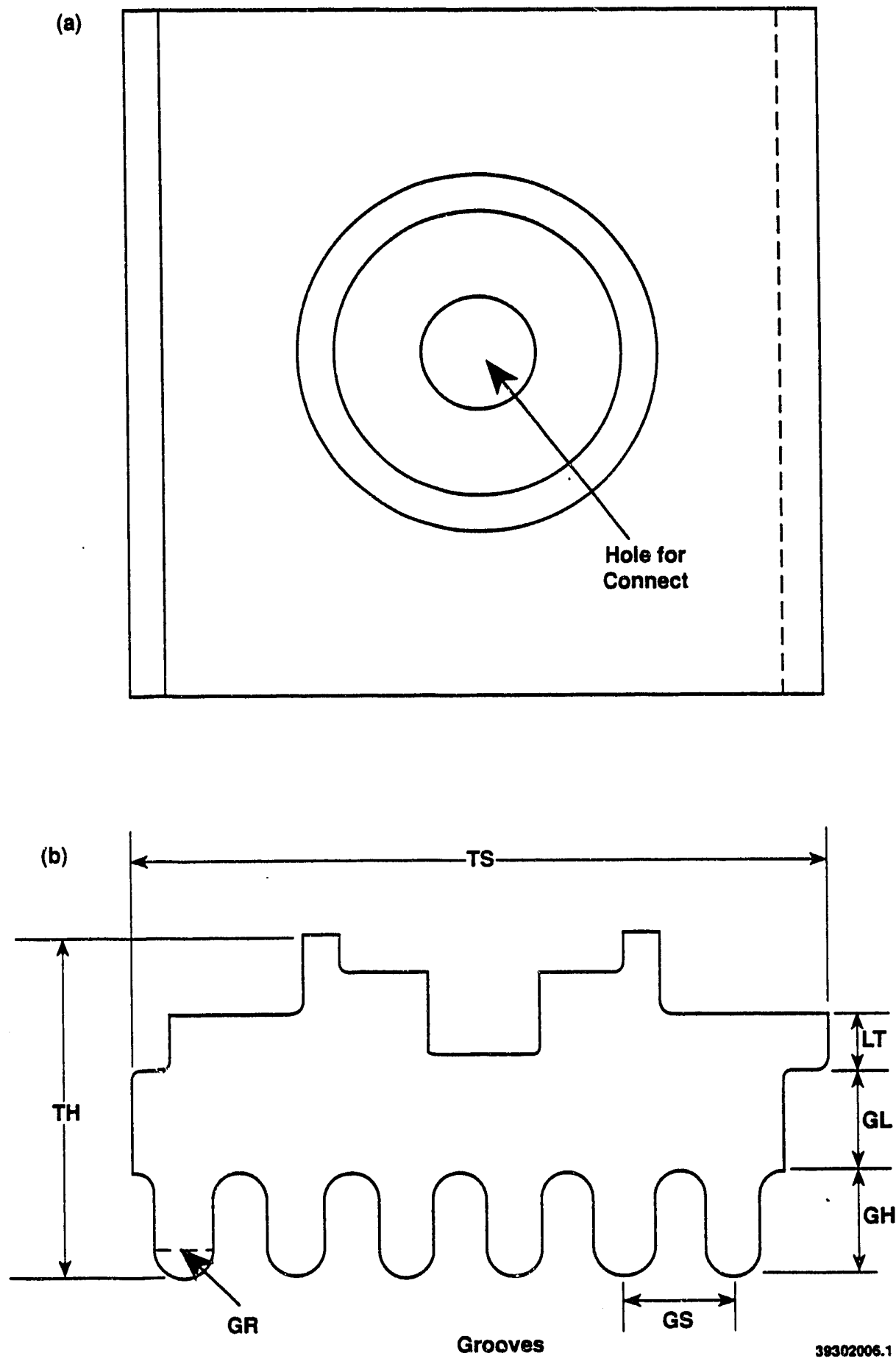

Figure 1.3. Key Features of the Advanced Design Anode: a) Top View; and b) Side View. Symbols are given for imporant dimensions. Values for these dimensions are given in the text. 
anodes (Windisch et al. 1992a). Briefly, this procedure called for blending the raw materials $\mathrm{Fe}_{2} \mathrm{O}_{3}$ $(48.3 \mathrm{w} / \mathrm{o})^{(\mathrm{a})}$ and $\mathrm{NiO}(51.7 \mathrm{w} / \mathrm{o})$, calcining them, and then milling the resulting mixture. Spray drying was also performed except in the cases that are noted later in this report. This second batch of powder was not analyzed extensively. It was assumed that its properties were similar to those of the first (pilot cell) batch that was characterized previously. As in the previous preparations, the ceramic powder was blended with $\mathrm{Cu}$ powder $(17 \mathrm{w} / \mathrm{o})$ before further processing.

After fabricating the anodes, CMI was to ship them to PNL for analysis. The analysis performed at PNL was to include: 1) characterization of appearance, including the overall shape as compared to the target shape, the dimensions of the anode, and the pi esence and nature of any flaws; 2) measurement of density; and 3) characterization of mic costructure and the composition of phases within the anodes. The results of these analyses are discussed in this report. Other information in this report includes various observations and comments regarding fabrication procedures by CMI staff.

Four anodes or parts of anodes fabricated by various approaches were received from CMI. These anodes are identified in Table 1.2. The first anode received, CM-I, was made by isostatic pressing; receipt of this anode satisfied the principal requirement of the purchase agreement, i.e., the delivery of one anode with advanced design. Anode CM-II was the result of an early isostatic pressing run. The other two anodes, CM-III and CM-IV, were preliminary attemf's at using approaches that had never been tried on this cermet material. They were provided not as prototypical anodes but for information purposes only. As it turned out, these pieces provided some very interesting information concerning the two alternative approaches that should be considered in planning any future development work on advanced design anodes.

In this report, each of the three fabrication approaches is discussed in a separate section. In each section, the approach is first described, comments on the fabrication procedures and any difficulties encountered are discussed, and the result of the post-fabrication analyses are given. Finally, after all of the approaches are discussed, conclusions regarding the three approaches and recommendations for future development work are given.

Table 1.2. Advanced Design Anodes Fabricated by CMI

$\begin{array}{ll}\text { Anode } & \text { Fabrication Procedure } \\ \text { CM-I } & \text { Isostatic Pressing } \\ \text { CM-II } & \text { Isostatic Pressing } \\ \text { CM-III } & \text { Injection Molding } \\ \text { CM-IV } & \text { Slip Casting }\end{array}$

Date Received at PNL $9 / 30 / 1992$

$10 / 15 / 1992$

$10 / 15 / 1992$

11/16/1992

(a) $w / 0=$ weight percent. 


\subsection{Isostatic Pressing}

\subsection{Description of Fabrication Approach}

The procedure used for isostatic pressing of the advanced design anodes was similar to that used for the pilot cell anodes (Windisch et al. 1992a). In isostatic pressing, a mold is filled with powder and then subjected to high pressure transmitted through liquid in a pressure vessel. The mold deforms to compress the powder and regains its original shape when the pressure is released. At $\mathrm{CMI}$, the loose, dry cermet powder was poured into a rubber "bag" with wall thickness of approximately $0.125 \mathrm{in}$. and inside dimensions approximately $35 \%$ larger than the desired anode size. The rubber container was restrained on the outside by a perforated metal container that fit loosely on the outside of the bag and kept the rubber from distorting by the weight of the powder. While filling, the assembly and powder were vibrated to eliminate any air pockets and powder bridging. The fill opening was then "corked" and the assembly pressurized while immersed in a fluid. Pressurization achieved about half of the shrinkage from bag size to sintered size. Sintering achieved the rest of the shrinkage.

This procedure is usually limited to simple shapes (bars, rods, cones, disks, etc.) becar'se the pressed piece has to be removed from inside the bag/container. The cutside dimensions are also usually somewhat irregular due to the relative freedom of movement of the powder within the bag before pressing. Stiff rubber or plastic bags that could be formed to the anode shape are not useful to form parts as they do not transmit enough of the hydraulic pressure to the powder and no useful compacting occurs.

To approach the isopressing of the anode contours, aluminum pieces were made to the same shape as the casting molds; various rubber inserts formed the lap-joint and electrode recess surfaces. The entire assemblage was inserted in a square surrounding rubber case and plug. The total combination was isopressed in several trials of pre-packing and, subsequently, removal of lap-joint and electrode contours. None were successful; most exhibited over- or under-pressed areas tied to crosssection variations and all cracked in the middle of the grooved sections.

The final approach taken to address the above problem appeared to work well. Keeping the same contoured aluminum parts, the outer rubber case was removed and a large, thin-walled, balloon was placed, instead, inside the metal parts. The balloon was filled with powder and then evacuated. This allowed the metal parts to move and shape the powder with atmospheric pressure. This created a compact strong enough to remove the metal parts and move the shaped piece in the balloon into the hydraulic press. Without the restraining metal the piece could move sufficiently for final compaction and "spring back" when removed from the press.

Similar to the pilot cell anodes, the consolidation pressure was $13 \mathrm{ksi}$. Sintering conditions were the same for all of the fabrication approaches and closely followed the earlier pilot cell anode runs (Windisch et al. 1992a). Briefly, the temperature was ramped up to $1200^{\circ} \mathrm{C}$ using a $88-\mathrm{h}$ schedule under a controlled atmosphere containing $100-200 \mathrm{ppm} \mathrm{O}_{2}$. 


\subsection{Observations During Fabrication}

The isostatic pressing of the anode proceeded reasonably well. This success was partly due to the experience gained at PNL over previous years of fabricating smaller anode pieces by this method and also to the experience gained by CMI during fabrication of the anodes for the pilot cell test (Windisch et al. 1992a). Nevertheless, the size and complexity of the advanced design anodes contributed to additional challenges in fabrication (Section 2.1).

The complexity of the shape of the anodes necessitated that a few simplifications be made in this first series of fabrication attempts. These simplifications concerned the top side of the anode (Figure 1.3a). In particular, the hole for the connector rod was not pressed into the piece, but machined instead. In addition, no ridges were made on the top side for the purpose of protecting the electrical connection. These two simplifications facilitated fabrication of the mold, which was already quite complex due to the grooved bottom. A significant amount of tooling was required in this approach. At $\$ 3,000$ to $\$ 4,000$ per trol modification and 50 to $60 \mathrm{lbs}$. of ceramic powder per attempt, it was considered more profitable to focus on the overall shape and the accuracy of the grooved side rather than on other details of the design that could be addressed more carefully at a later time.

The isostatically pressed anode was massive, $62 \mathrm{lbs}$, after sintering. Linear shrinkage during firing was about $20 \%$; volume shrinkage was about $73 \%$ (both based on fired size). In general, there was significant displacement of material during firing. To allow this movement of material without tearing during sintering, the anode was placed in a thick cushion of alumina sand. The alumina acted as little rollers between the piece and the supporting refractory tile. This appeared to give the required "lubrication" but created additional problems as discussed below. The piece was fired with the grooved side pointing upward to allow the most fragile surface the maximum freedom to shrink.

A significant amount of metal (that was mostly $\mathrm{Cu}$ in content as discussed in Section 2.3) was lost from the anode as "bleed-out" during sintering. One of the important problems this created (in addition to loss of metal phase from the anode) was that a crust formed on the surfaces of the anode that were in contact with the alumina powder. As discussed in Section 2.3, it is believed that this crust formed as a result of a reaction between the exuded $\mathrm{Cu}$ and the alumina powder.

As discussed in Section 2.3, the Cu bleed-out may be due to the relatively small amount of binder in the ceramic powder. The CMI ceramic powder contained $2 \mathrm{w} / \mathrm{o}$ binder compared to about $4 \mathrm{w} / \mathrm{o}$ for ceramic powder previously used by PNL and manufactured by Stackpole, Inc. (Pittsburgh, Pennsylvania). Additional binder posed its own problem in the fabrication however. Some large pieces were also fabricated using Stackpole powder, and all of them cracked during even the most gentle of burn-out cycles. This was because of the large mass coupled with the very poor heat conductivity of the green pieces. Apparently, the outside pores of these pieces closed up before the inside reached temperatures high enough to vaporize the binder. Binder trapped inside the anode eventually vaporized and burst the anode.

The effect of binder burn-out is a common problem in fabricating large ceramic parts using any forming process, but is generally minimized in isostatic pressing. The approaches for solution are also generally known in theory, but are somewhat "cut-and-try" in application. Multiple binder 
combinations with graded vaporization temperatures are the principle. They usually have to be worked out on a piece with a mass and surface area similar to the desired product. Sufficient resources were not available to optimize the binder burn-out conditions during this preliminary study. Such an effort should be part of any follow up study if isostatic pressing becomes the method of choice for making the advanced design anodes.

\subsection{Post-Fabrication Analysis}

This section covers the results of analyses performed at PNL on the advanced design anode, CM-I, fabricated by CMI using isostatic pressing. Limited analysis of another isostatically pressed cermet piece, CM-II, was also performed and is reported here.

\subsubsection{Appearance}

The shape of CM-I, shown in Figure 2.1, was very close to the target shape (Figure 1.3). The anode had a grooved surface on one side, ledges for interlocking on two of the other sides and a flat surface on top. The top also had a hole in it for connection of an electrical connector rod. There were two notable exceptions to the similarity between CM-I and the targeted design: 1) the top surface was flat and had no ridges as planned to facilitate joining of the connector rod and provide protection during operation (Figure 1.3); and 2) the hole in the top of CM-I was machined into the piece rather than molded. As indicated in Section 2.2, these changes were made to facilitate fabrication in this first series of attempts. Key dimensions of CM-I are given in Table 2.1 along with the target dimensions. In all cases, except for the lip thickness which was affected by the way in which the top surface was molded, the measured values were very close to the target values.

CM-I exhibited no serious flaws such as cracks or fissures on any surface when scrutinized visually. Significant bleed-out of metal was observed on some faces of the anode and is shown in Figure 2.1b. (Actually, metal bleed-out occurred on all surfaces but was cleaned off the top and the grooved side by CMI for display purposes.) The exuded metal was reddish-colored indicating that it was mostly $\mathrm{Cu}$. Cut surfaces of $\mathrm{CM}-\mathrm{I}$ were also redder in appearance than anodes made previously at

Table 2.1. Key Dimensions of CM-I

\begin{tabular}{|c|c|c|c|}
\hline Description & Symbol & CM-I, in. & Target, in. \\
\hline Top Surface (Square) & TS & $8 \times 8$ & $8 \times 8$ \\
\hline Total Height & TH & 4.6 & 4.5 \\
\hline Grove-to-Lip & GL & 1.26 & 1.25 \\
\hline Groove Height (or Depth) & GH & 1.5 & 1.5 \\
\hline Groove Separation & GS & 1.5 & 1.5 \\
\hline Overhanging Lip Thickness & LT & 1.75 & 0.75 \\
\hline
\end{tabular}




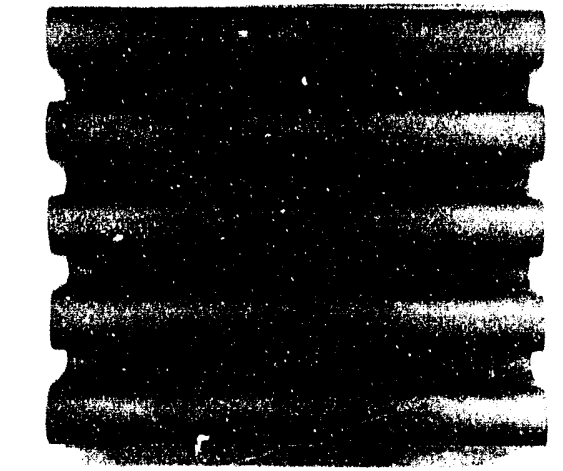

(a)

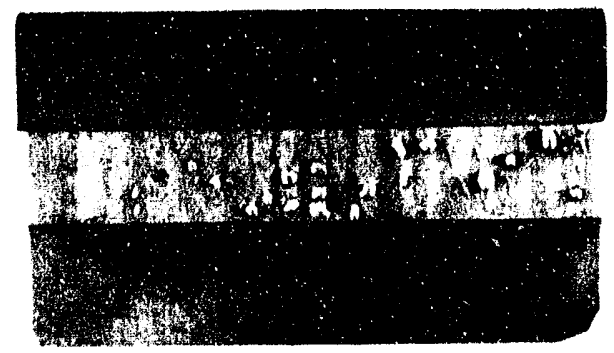

(c)

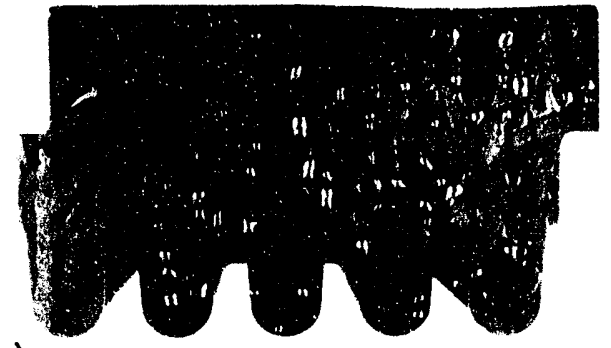

(b)

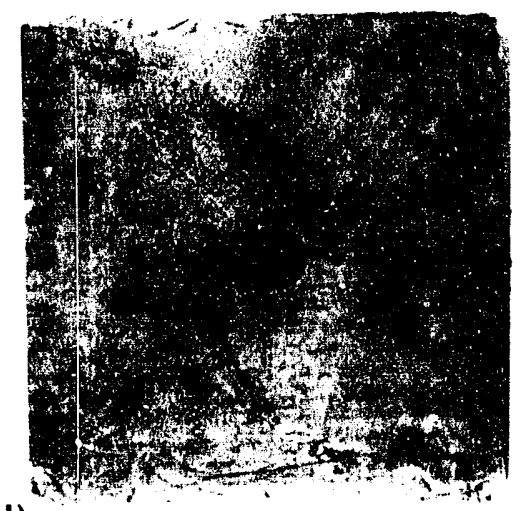

(d)

Figure 2.1. Views of CM-I: a) Bottom View Showing Grooves; b) Side View Showing Grooves; c) Side View; and d) Top View Showing Hole for Connector Rod

PNL suggesting a more $\mathrm{Cu}$-rich metallic phase. According to CM-I, the metal that bled out on the top side reacted with the alumina powder that was used to support the anode in the furnace during sintering. This reaction produced a crust, as shown on CM-II in Figure 2.2, that was manually cleaned from CM-I. The crust formed from an apparent reaction between the exuded metal, which was mostly $\mathrm{Cu}$ as discussed below, and the alumina support. It is believed to be, at least partly, composed of copper aluminate based on previous studies (Strachan et al. 1988).

Ultrasonic testing was performed on CM-I to try to find any defects within the material prior to obtaining core samples. This nondestructive method had been applied very successfully to the cermet anodes used in the pilot cell test and details of the approach were discussed previously (Windisch et al. 1992a). Ultrasonic scans were obtained on CM-I for various orientations. Figure 2.3 shows a scan from the top, flat surface of the anode. Reflections of the probe signal are indicated by the appearance of white and light gray regions in this black-arld-white photograph. These reflections can be due to variations in the anode dimensional structure (i.e., at the top of a groove or at a ledge) and to flaws within the anode material. The gray circle in the center is from the bottom of the connector rod hole; the gray band on one side of the square is due to the ledge on that side of the anode; and the parallel gray and white bands are partly due to the grooves on the bottom of the anode. The more 


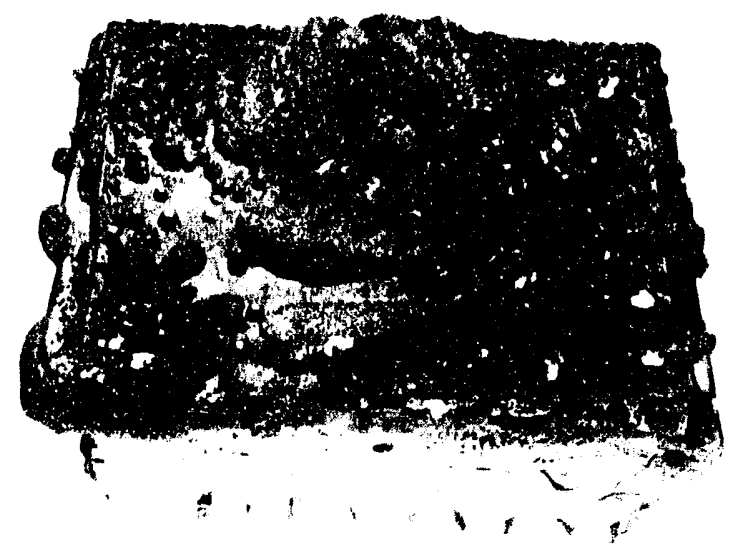

Figure 2.2. Anode CM-II Showing Crust on Top Surface

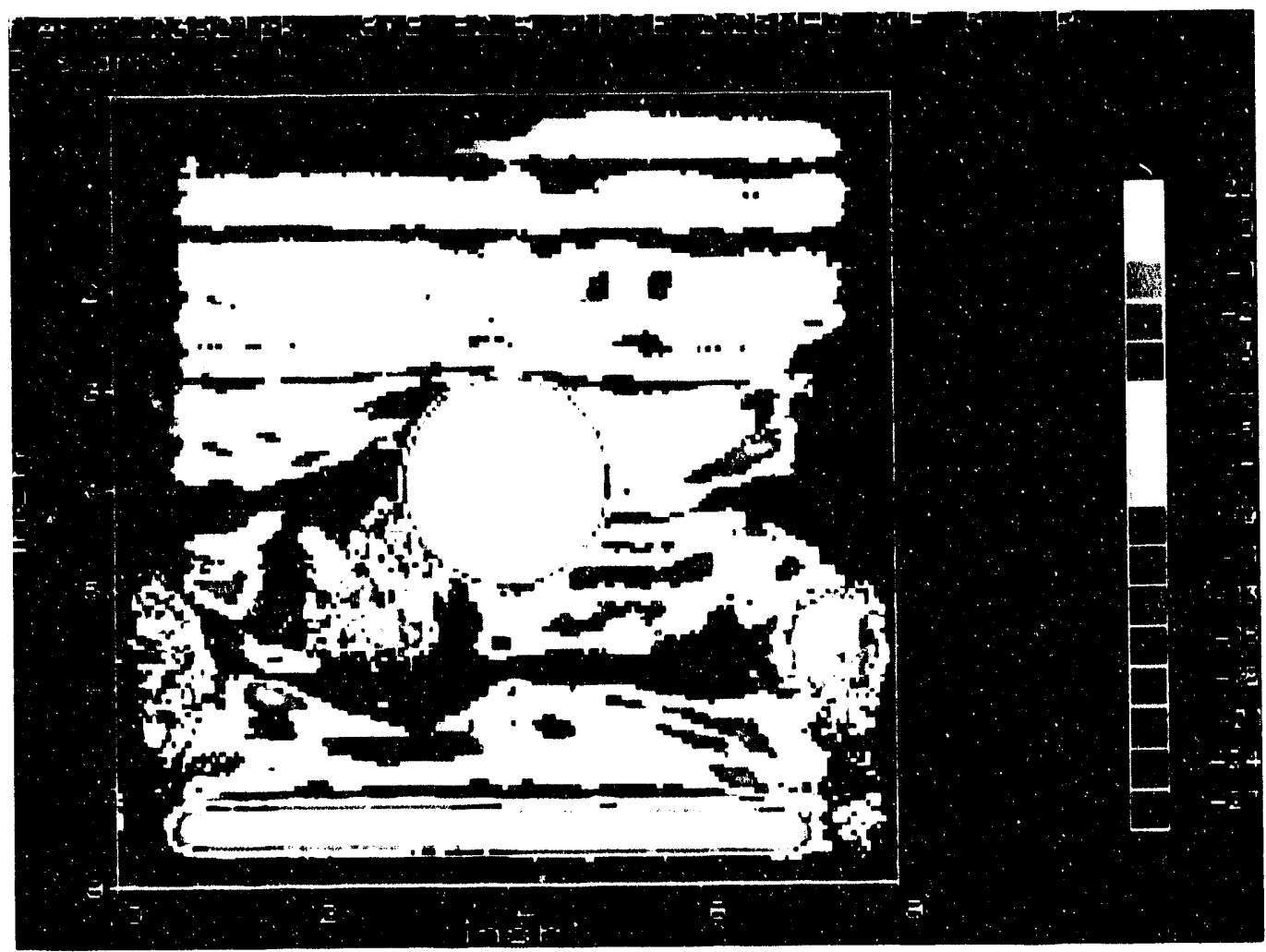

Figure 2.3. Ultrasonic Scan from Top Surface of CM-I 
randomly distributed gray and white patterns are due to reflections from what was first believed to be flaws. Further analyses, as discussed below, indicated that they were probably not due to flaws, but more likely due to compositional variations.

Figure 2.4 shows an ultrasonic scan from one of the sides of the anode. The approximately 1-long reflection in the center is the bottom of the electrical connector hole. Between this reflection and the top of the anode (light gray band) are a series of roughly parallel planes of reflection. These reflection planes were believed to arise from the same source as the unidentified reflections in Figure 2.3.

\subsubsection{Density}

Densities were measured on seven samples from cylindrical core sections removed from CM-I. The mean density was $5.75 \pm 0.06 \mathrm{~g} \mathrm{~cm}^{-3}$. This density is significantly lower than the density measured on anodes previously made at PNL $\left(6.05-6.10 \mathrm{~g} \mathrm{~cm}^{-3}\right)$. The lower density resulted, at least partly, from the lower consolidation pressure used by CMI for the grooved anodes. A similar result was observed for the pilot cell anodes that were also consolidated at the lower pressure (Windisch et al. 1992a). The lower density for CM-I may also have been partly due to the fact that

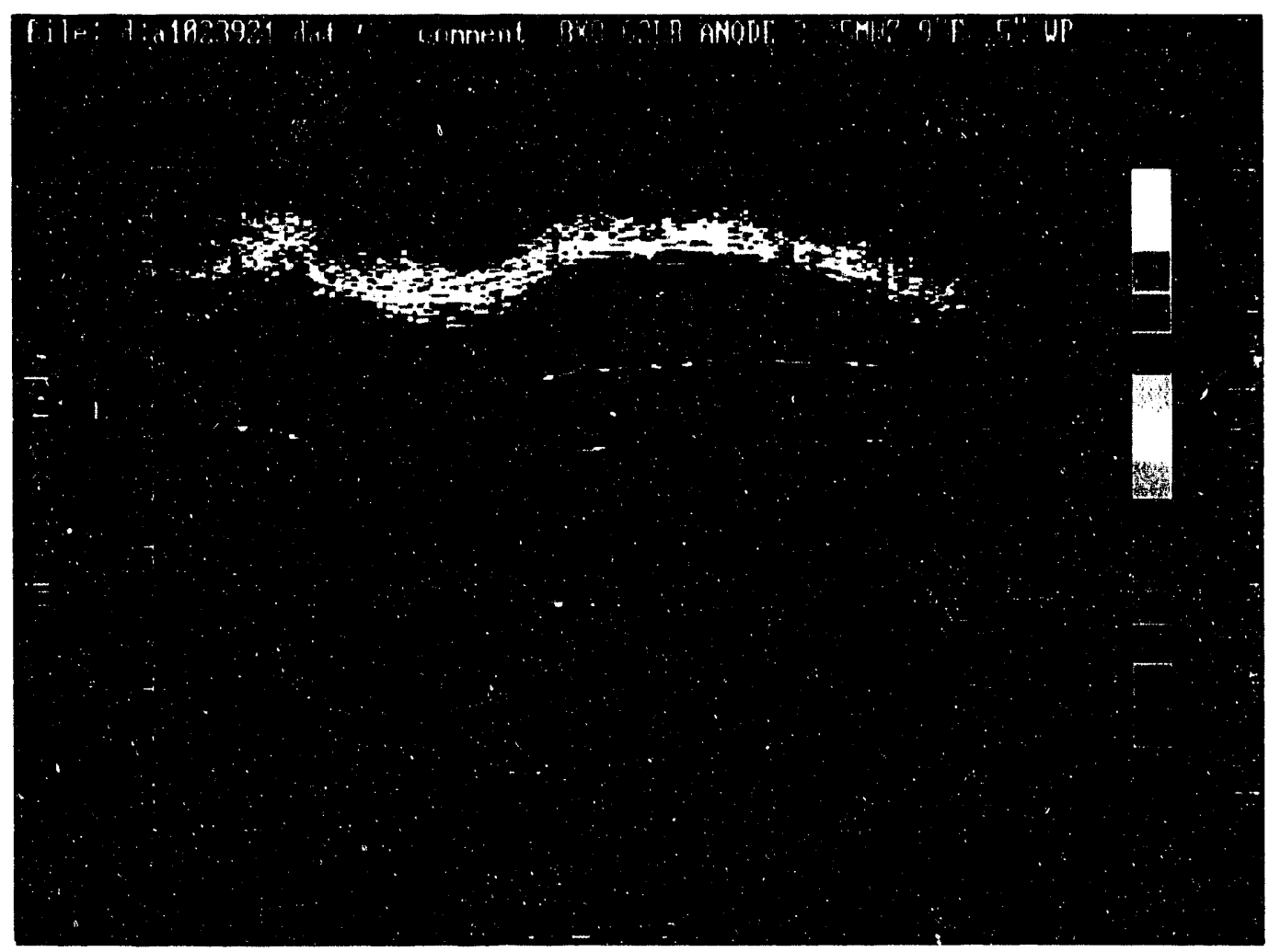

Figure 2.4. Ultrasonic Scan from Side Surface of CM-I 
less reaction involving residual binder occurred during sintering. As reported in Section 2.2, effort was made to burn out as much of the binder as possible before sintering to avoid cracking due to trapped gases. The presence of some binder during sintering, however, may also afford some densification via reactions that contribute to alloying and alterations of microstructure (Section 2.3.3).

\subsubsection{Microstructure and Composition}

Two, 1-inch-diameter, core sections were removed from CM-I. Five, approximately 1-inchtall, samples were then cut from each of these core sections to study microstructure and to identify the source of the reflections in the ultrasonic scans (Section 2.3.1). The density measurements reported in Section 2.3.2 were performed on seven of these samples. The core sections, labelled A and $\mathrm{B}$, were drilled out of $\mathrm{CM}-\mathrm{I}$ from the top of the anode and down through it, including regions that had strong reflections in the ultrasonic data (Figure 2.3). Core section A was taken from a region with stronger reflections than from where $B$ was removed.

The two core sections, A and B, showed no apparent flaws from the outside. However, ultrasonic traces on the core sections themselves showed reflections that correspond to those obtained on the whole anode (Figures 2.3 and 2.4). As expected, the reflections were more intense for core section A than for core section B.

Optical microscopy and scanning electron microscopy (SEM) on four of the samples revealed a number of interesting features of the microstructure of CM-I, some of which differed significantly from that of anodes previously made at PNL and CMI. As shown in Figure 2.5, CM-I exhibited a

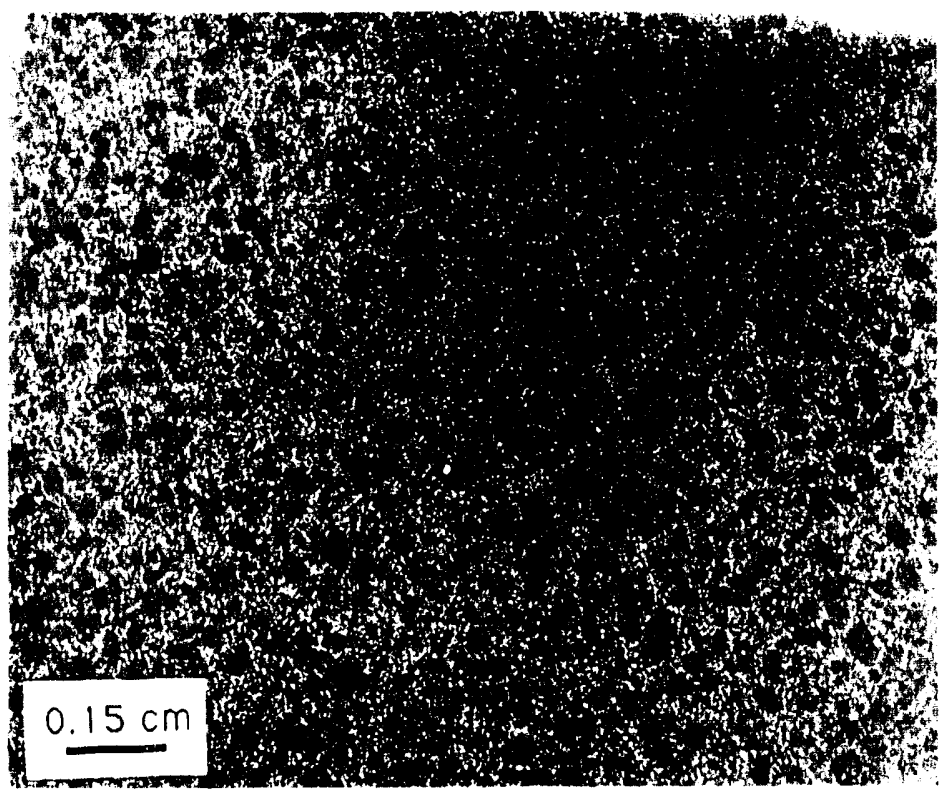

Figure 2.5. Optical Micrograph of Sample from CM-1 
very unusual distribution of the metal phase. The alloy appeared to wind around in a "stringy" fashion, leaving alloy-poor regions in the spaces between the strings. In the regions where there was less alloy phase, the material also appeared to be more porous (Iigure 2.6). Energy dispersive $x$-ray spectroscopy (EDS) analysis of the metal phase indicated that it was over $95 \mathrm{a} / \mathrm{o}^{\text {(a) }} \mathrm{Cu}$, which is more $\mathrm{Cu}$-rich than in any anode previously made at PNL or CivI (generally $75-85 \mathrm{a} / \mathrm{o} \mathrm{Cu}$ ). This analysis was also consistent with the red color of the exuded metal. As shown in the SEM images in Figure 2.7, the microstructure was also "granular" in appearance, i.e. with phases that looked less consolidated and seemed to have sharp boundaries, unlike anodes made previously at PNL which showed a more "liquid-like mixing" of the phases. Another important difference was that the alloy phase in CM-I was bordered by both of the oxide phases (NiO and ferrite), whereas the alloy phase in anodes made at PNL was usually just bordered by the ferrite phase (dark gray phase in Figure 2.7).

Other than those features reported above, no distinguishing microstructural characteristics of any of the CMI samples were found that could be correlated with the reflections in the ultrasonic data reported above. In particular, no cracks or fissures could be found at positions near where the ultrasonic reflections occurred. As shown in Figure 2.4, some sort of flaw was expected at about 1 inch from the top surface; but no obvious source of the reflection was found. The conclusion, at this point, is that the reflections arose from more subtle microstructural or, alternatively, compositional

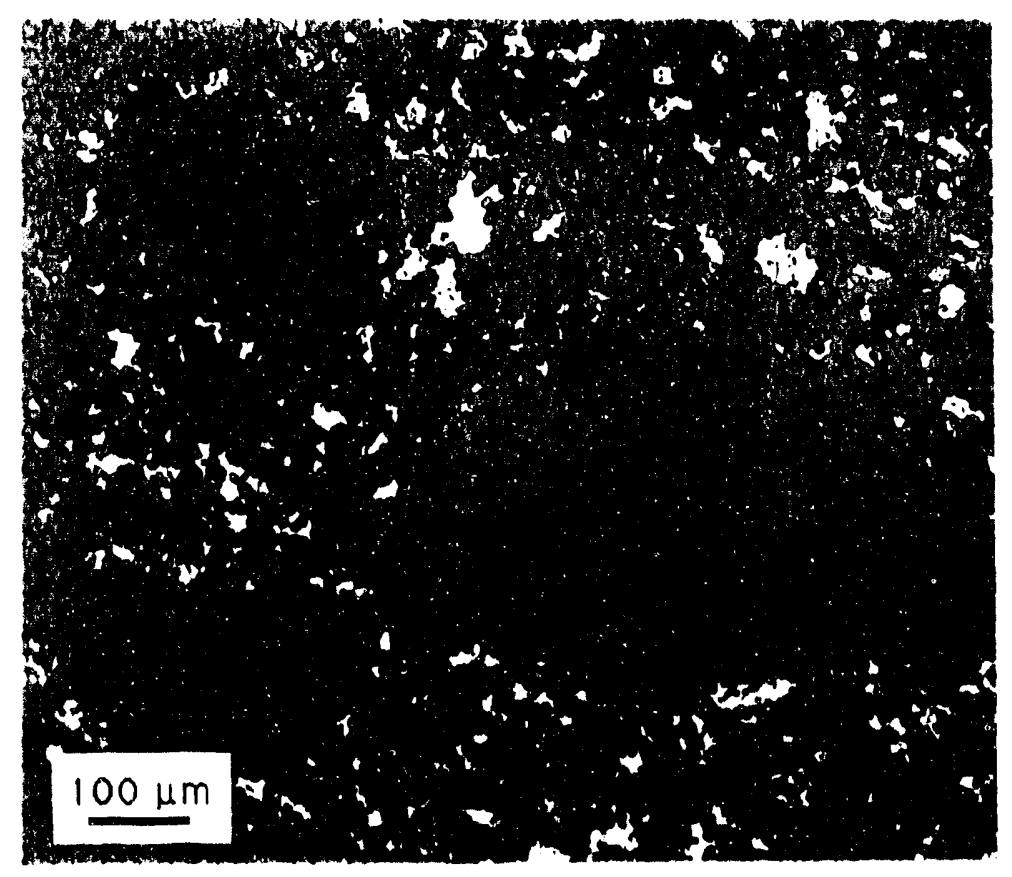

Figure 2.6. Optical Micrograph of Sample from CM-I Showing Porous Region Between Alloy "Strings"

(a) $\mathrm{a} / \mathrm{o}=$ atom percent. 

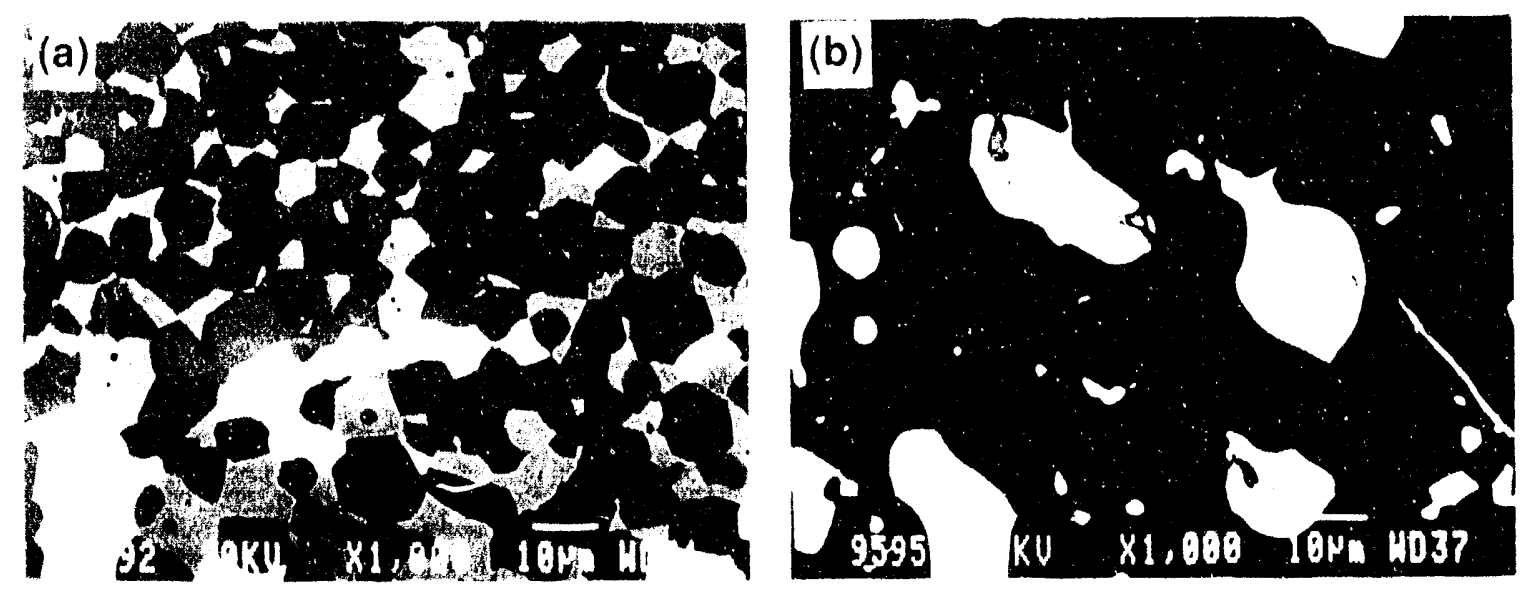

Figure 2.7. SEM Micrographs of: a) Sample from (M-I; and b) Sample from PNL. Anode

variations (such as the distribution of the metal phase as seen from another perspective or the composition of the metal phase itself that somehow escaped detection. It is doubtful that the ultrasonic data were in error because of the success of the technique in the past on the cermet material (Windisch et al. 1992a). Admittedly, the technique's sensitivity to all of the possible variations in the cermet material has not been determined, which contributed to our current inability to identify the source of the reflections in CM-I.

\subsection{Conclusions}

The microstructural results for CM-I appear to be consistent with the measured physical properties and fabrication procedures. A combination of the lower consolidation pressure and lower concentration of binder during sintering probably resulted in the lower material density. The binder burn-out prior to sintering was probably responsible for regions of higher porosity within the anode and, indirectly, on the unusual distribution of the alloy phase, although the specific reason for "stringy" appearance is unclear. Additionally, the lower concentration of binder during sintering probably resulted in a lower amount of alloying of $\mathrm{Ni}$ (via reduction of some $\mathrm{Ni}$-containing oxide) with the Cu. A more Cu-rich phase would be more likely to melt and flow during sintering, which would explain the higher amount of metal bleed-out during this step. Also related to the presence of some birider during sintering appears to be the "affinit," of ferrite for the alloy phase as observed in the SEM images. CM-I, with its lower binder content, gave no evidence for this affinity.

From a fabrication standpoint, isostatic pressing appears to be relatively close to achieving an advanced anode with the desired shape. Furthermore, while the microstructure and phase composition of CM-I were significantly different from previous anodes made at PNL, it appears that with further development work the desired microstructures and compositions could be achieved. To accomplish this result, the following refinements to the procedures would seem to he in order:

- The consolidation pressure should be higher (about $25 \mathrm{ksi}$ ) to match the conditions previously implemented at PNL. 
- A more effective use of binder needs to be investigated, perhaps with a graded design as discussed in Section 2.2. The concentration and burn-out conditions should be adjusted to minimize the formation of pores without leading to cracks during sintering. Conditions necessary for minimizing metal bleed out and attaining a less "granular" microstructure in the final product also need to be determined; although these problems may be corrected by optimizing the use of binder as indicated above.

- Additional tooling and procedures need to be developed to introduce the specified features (e.g. electrical connector hole) in the top of the anode during processing. Contoured balloons that match the outer metal pieces need to be used to reduce wrinkles in the molded cermet surface and optimize the dimensions of the lap-joint edges.

- A better strategy for eliminating the formation of the crust during sintering should be identified; this problem may be corrected by reducing metal bleed-out through the more efficient use of binder as indicated above. 


\subsection{Injection Molding}

\subsection{Description of Fabrication Approach}

The injection molding process is described by Segal (1989) as follows:

"Injection molding is a plastic forming technique in which ceramic powder is added as a filler to an organic polymer, usually a thermoplastic, to form a plastically deformable mixture that is injected, using a combination of heat and pressure, by a plunger into the mold. The viscosity before injection is an important parameter for controlling even filling of the mold and avoiding air bubbles in finished components. Large amounts of polymer are used, typically up to $30 \mathrm{v} / 0,{ }^{(a)}$ although solid content in the mixture can be maximized by optimization of the particle size, but binder removal is a difficult step as it can produce cracking and voids. Injection molding is used extensively in the plastics industry and has the potential for production of components with complex shapes such as turbine blades."

An excellent review of injection molding is also given by Edirisinghe and Evans (1986). This approach was adapted to the cermet material and attempted by Certech, Inc. (Wood Ridge, New Jersey) under the direction of CMI and with approval of PNL and DOE-HQ. Certech, Inc. is a world leader in injection molding of ceramics, and they manufacture their entire product line by this method.

The feed mate ial for this process was not spray dried. The dried mill cake was pulverized and the copper powder admixed by tumbling in a dry blender. The latter operation was the same as performed on spray-dried powder.

The cermet was then combined with a proprietary binder, primarily a multi-component thermoplastic, in a high shear mixer. The binder was preheated and additional heat was generated by the shear energy from mixing to a temperature of about $45^{\circ} \mathrm{C}$. Solid/binder ratio was $70 / 30$ by volume.

After mixing and cooling, the resulting cake was loaded into the chamber of a low-pressure, ram-type injection molding machine of capacity suitable for the mold used. The mix was heated to $30^{\circ} \mathrm{C}$ and injected at 1000 psi or slightly higher. All subsequent work was performed with this lowpressure system. Low-pressure formulation was chosen to keep mold clamping pressure requirements for the large anode within reasonable levels. The anode was to be the largest ceramic piece ever injected.

(a) $\mathrm{v} / \mathrm{o}=$ volume percent. 


\subsection{O’servations During Fabrication}

Early work involved small test bars and was quickly moved to larger molds from the Certech, Inc. inveritory. CM-III was the largest piece fabricated by this method; but even CM-III was significantly smaller than the target specifications for the advanced design anode. Early trials on small specimens were promising. For irger specin ans sucn as CM-III, however, two serious difficulties were encountered. It was concluded that bcth of these difficulties would need to be remedied prior to recommending ine method fo: making cermet anodes.

The first problem concerns the tendeucy for larger pieces, inciuding CM-III, to develop cracks or fissures during the molding process. The molding material did nist appear to "wet itself" sufficiently as it went into the mold. Surfaces didn't rejoin and fissures (and flow lines or seams) were, consequently, introduced. Clearly, if this fabrication approach were to be pursued further, significant deveiopment work would need to be done on the binder composition to impart the required physical properties to the molding material.

The second difficultly concerns the hinder removal prior to sintering. As the size of the piece was increased, the difficulty in removing binder also increased. In addition, the binder burn-out had to be performed under nitrogen becsusc., when air was used, excessive oxidation of the cermet occurred. Unfortunately, for most inateriais, experience shows that binder burn-out is usually more efficient in air. The best burn-out procedure for the cermet appeared to be an extended heating cycle at 200 to $350^{\circ} \mathrm{C}$ in flowing nitrogen, with the piece embedded in fine alumina powder which served as a wick to drain out the molten binder and to retain to while being vaporized by the nitrogen. The difficulty in removing binder was also aggravated by the proportionally large quantity of binder used in this approach. In all likelihood, a significani amount of binder was left in the material when sintering was initiated, compared to the other fabrication methods evaluated in this study. This residual binder is believed to he partly responsible for the different microstructure and phase compositions observed for CM-III (Section 3.3.3).

From a fabrication standpoint, it is believed that this approach would be difficult to implement without significant work to develop a successful binder for the cermet material. This binder must impart the required "flow" characteristics to the cermet material during molding and, at the same time, lend itself to a reliable burn-out procedure prior to sintering. Experience with the cermet anodes suggests that some burn-out of the binder is necessary (a proportionally large fraction for an injection molded piece) but that a small amount should be left behind to induce the desired microstructure and phase compositions (Section 3.3.3). Clearly, a successful resolution of these problems would entail significant trial-and-error evaluations of a variety of materials and processing conditions. If successful, however, this approach would seem to have the best potential for achieving the detail: of the desired shape.

\subsection{Post-Fabrication Analysis}

This section covers the results of analyses performed at PNL on the cermet piece CM-III fabricated by CMI using injection molding. 


\subsubsection{Appearance}

As shown in Figure 3.1, the CM-III was a $10-\mathrm{lb} ., 14 \mathrm{~cm} \times 14 \mathrm{~cm} \times 4 \mathrm{~cm}$ block with a checkerboard appearance on one of the large faces. The other large face was finished off to reveal the fissures inside the piece. The fissures were introduced during the molding process as discussed in Section 3.2. A few small beads of metal were also observed on the outside surface of CM-III. These beads were far fewer in number than observed on CM-I and were also more silver-colored. Cut surfaces on CM-III were also silvery in appearance, in contrast to CM-I which was more Cucolored. This is consistent with the higher Ni-content of the alloy phase in CM-III as discussed in Section 3.3.3.

Since CM-III was purposefully not made to dimensional specification, unlike CM-I and CM-IV, no further discussion on the shape of CM-III is given in this section.

\subsubsection{Density}

A single, 1-in.-diameter core section was removed from CM-III and subsequently cut into cylindrical samples. Density measurements on two of these samples were sensibly identical at $5.95 \mathrm{~g} \mathrm{~cm}^{-3}$. This was the highest value for the three grooved anodes made by CMI and was closest to the specification range of $6.05-6.10 \mathrm{~g} \mathrm{~cm}^{-3}$. Furthermore, the "intrinsic" density of CM-III may have been even higher than that measured because there were numerous fissures in the anode and it was hard to be certain that the pieces measured were completely free from these defects. The higher density of CM-III is also consistent with its microstructure (Section 3.3.3), which was more similar than the other grooved anodes to anode materials previously made at PNL.

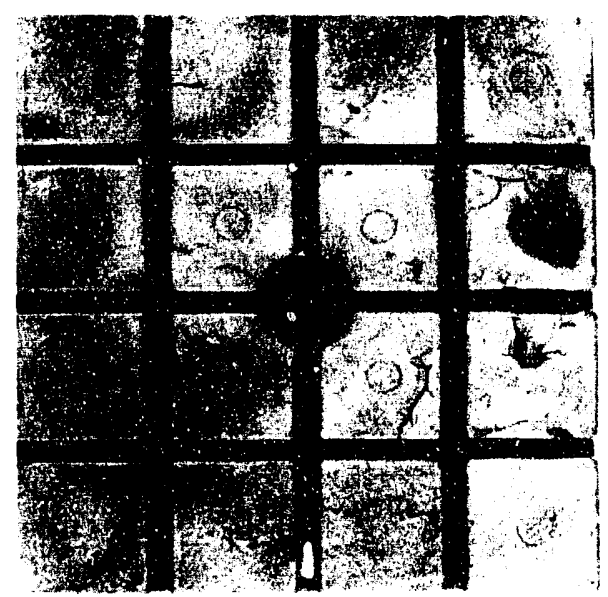

(a)

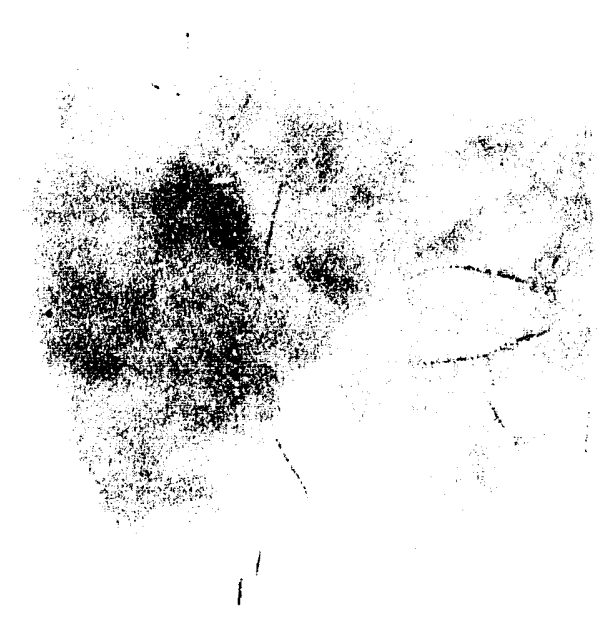

(b) Figure 3.1. Views of CM-III: a) bottom Surface Showing Checkerboard; b) Top Surface
after Finishing 


\subsubsection{Microstructure and Composition}

As shown in Figure 3.2, the microstructure of CM-III was similar to that of anodes previously made at PNL (except for the larger fissures discussed earlier). In particular, the material was low in porosity and showed a more intimate mixing of the phases, i.e. less "granular" than CM-I and CMIV. Also similar to PNL anodes, the alloy phase was usually bordered by only ferrite (dark gray phase in Figure 3.2). Analysis of the alloy indicated that it was about $66 \mathrm{a} / \mathrm{o} \mathrm{Cu}$ and $32 \mathrm{a} / \mathrm{o} \mathrm{Ni}$. This is much richer in Ni than the alloy phases in CM-I, CM-IV, and even the PNL anodes (15 - 25 a/o $\mathrm{Ni})$.

Figure 3.3 shows one of the fissures in CM-III. The fissures varied in width and sometimes contained metal phase which appeared to have flowed into it. Consistent with the observations made in Section 3.2, the fissures appeared to have formed during molding and the metal partially filled them during sintering. The composition of the metal in the fissures was similar to the alloy in the bulk of the material.

\subsection{Conclusions}

The microstructural results for CM-III are consistent with the physical properties of the material and the fabrication conditions, and appear to explain the differences between this piece and the other CMI anodes, as well as some similarities to the PNL anodes. In particular, the higher density of CM-III is at least partly due to its "tighter" microstructure which was very similar to PNL anodes. It appears that reduction of residual binder during sintering was responsible for the development of this microstructure in CM-III. As indicated in Section 3.1, significantly more binder was present in the injection molding process. Even though steps were taken to burn out the binder carefully, with the high loading level employed it is likely that significant residuals remained. Presence of binder during
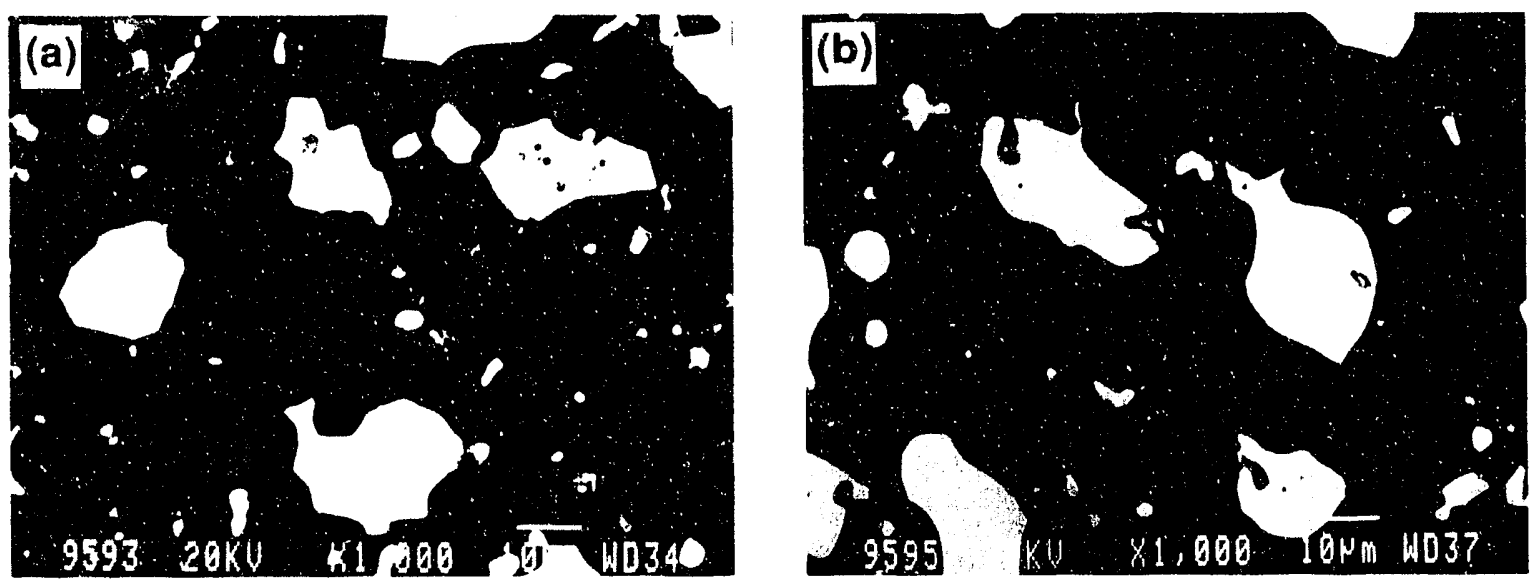

Figure 3.2. SEM Micrographs of: a) Sample from CM-III; and b) Sample from PNL Anode 


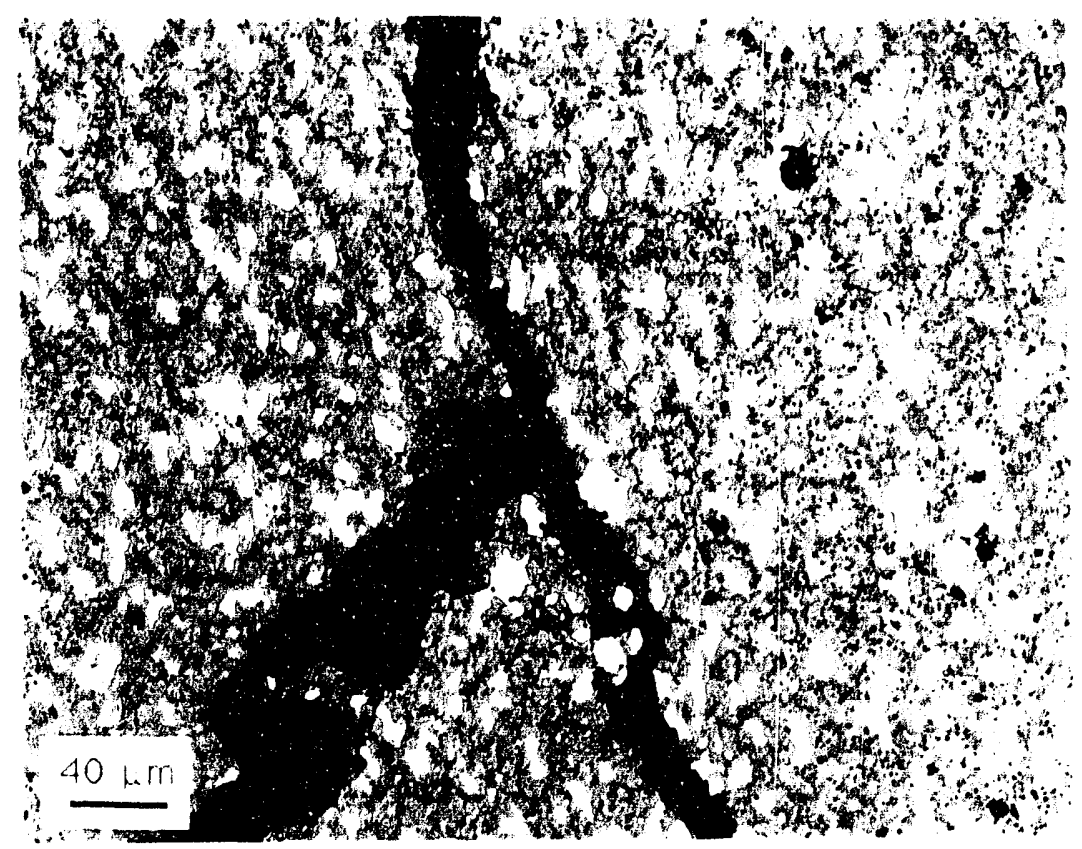

Figure 3.3. Optical Micrograph of Sample from CM-III Showing Fissures

sintering is believed to favor the reduction of some of the $\mathrm{Ni}$-containing oxides resulting in $\mathrm{Ni}$ alloying of the metal phase. The fact that the alloy phase in CM-III contained more $\mathrm{Ni}$ than any of the other anode materials suggests this process was especially important in developing the final composition and microstructure of CM-III. The proximity of the ferrite and alloy phases in the microstructure of CM-III may also be related to the reactions of the binder, but insufficient data were available to confirm or explain this.

A lower amount of metal bleed-out in CM-III compared to CM-I might be explained by the higher melting temperature of the $\mathrm{Cu}-\mathrm{Ni}$ alloy (in $\mathrm{CM}-\mathrm{III}$ ) relative to essentially pure $\mathrm{Cu}$ (in $\mathrm{CM}-\mathrm{I}$ ). Some melting of the metal phase in CM-III did occur during sintering, however, as evidenced by the filling of the fissures formed in the molding step. The effect on corrosion properties of slightly higher Ni contents in the alloy phase, compared to standard PNL anodes, is probably not significant because other high-Ni versions of the anode material were tested successfully in PNL laboratory cells. However, at significantly higher $\mathrm{Ni}$ contents, more corrosion will occur as evidenced by the work of Alcoa Laboratories (Weyand et al. 1986). Due to the difficulty in controlling the composition of the alloy phase precisely, the variation of corrosion properties with its composition has not been fully determined.

The fissures that formed during the molding process were due to the insufficiency of the organics to wet the material properly during molding. Clearly, this is the main limitation of using injection molding and it is doubtful that a satisfactory resolution could be obtained without significant further research. Engineering the anode to consist of smaller pieces might be a solution since injection molding with the common binder ingredients appeared to work best when the molded object 
was not so massive, however it is not certain how smaller anodes could be deployed in a commercial cell without other problems arising. Alternatively, a new binder system would have to be developed for the cermet material. It is anticipated that identifying a suitable binder for the cermet would require significant further development work. 


\subsection{Slip Casting}

\subsection{Description of Fabrication Approach}

The slip casting process is described by Segal (1989) as follows:

"Slips are suspensions of one or more ceramic materials in a liquid, usually water, with a particle size around $1 \mu \mathrm{m}$ and may be considered as colloidal systems. The slip casting technique involves pouring a slip into a porous mold often made from plaster of Paris or gypsum which absorbs liquid and deposits solid material at the mold walls. Excess slip is drained off after which the cast is removed and then fired. Slip casting is a very versatile technique and has been used for manufacture of tableware, sanitaryware, crucibles, tubes, thermocouple sheaths, and gas turbine stators. However, three factors affect the quality of a cast. First, particles must remain in suspension so that deposition occurs evenly on the mold walls. Secondly, high solid contents $(c a .70 \mathrm{w} / 0)$ improve the drainage rate and thirdly, low viscosity is required in order to prevent incorporation of air bubbles into the ceramic and to ease filling of the mold.

"As for other colloid dispersions, the stability of slips is controlled by interaction forces between particles. Strong ceramics can be obtained in the absence of particle aggregates, which are avoided by using deflocculating agents in the slip. These materials, normally surface-active agents, probably act by adsorption at the solid-liquid interface, for both oxide and non-oxide ceramics, which modifies the interaction energy between particles. However, particle size, $\mathrm{pH}$, and ionic strength affect slip stability and rheological properties of these systems, which are important for controlling liquid drainage from the dispersions."

The primary work in this approach was performed at the Rutgers University Center for Ceramic Manufacturing Methods Development (New Brunswick, New Jersey) under the direction of CMI and with approval of PNL and DOE-HQ.

Initially, the trials were run in a water-based system as is used throughout the ceramic industry. The premixed material, which was not spray dried and contained no binder, was milled into the liquid by a brief, 4-6 h, milling step using a steel ball with steel media. This is normal practice and is used to slip cast small simple shapes in nickel-zinc ferrites. It became apparent quickly that there was a chemical reaction between the $\mathrm{Cu} /$ water and the material of the mold $\left(\mathrm{CaSO}_{4} \cdot 2 \mathrm{H}_{2} \mathrm{O}\right.$ or gypsum), such that large excesses of water were required to maintain fluidity; and, when poured into the mold, the slip flocculated and would not cast freely. No dispersing agent was found which relieved this problem. The reaction was evidenced also by a blue-green color created in the plaster behind the casting surface.

It was also noted that the very fine particle size, large surface area, of the feed powder required much higher water ratios than normal for general ceramic casting. (Cast ferrites are normally made from coarser powders also.) However, high water ratios are normally avoided to reduce casting shrinkage and to aim for higher green density, better handling strength, less sintering shrinkage, and better microstructure. Unfortunately, coarsening the cermet powders was not a viable option at this 
point because the aim of the work was to obtain anodes with a microstructure similar to earlier anodes, and use of a coarse powder would certainly have changed the microstructure.

Low-temperature heating of the mixed powders under Ar was evaluated as a way to reduce the activity of the $\mathrm{Cu}$, but the best solution involved substituting an organic liquid for water. The liquid selected was toluol, mixed with an oil as a dispersing agent to achieve high solids content and polyvinyl butyrate (PVB) for green strength. The oil and PVB were both added at $1 \mathrm{w} / 0$ or less. The substitution of the organic medium eliminated the $\mathrm{Cu} /$ water/mold reaction problems. Small, cast test pieces were readily poured and sintered to reasonable densities. No $\mathrm{Cu}$ loss from the cast surface was found. Total shrinkage was determined and models made for preparation of the full size molds.

\subsection{Observations During Fabrication}

Attempts to make the full-size anode resulted in many problems, all size and shape related. The two most important problems in making CM-IV were: 1) failure of the material to "knit" well during molding; and 2) the formation of cracks during drying.

The first problem occurred during filling of the mold. The material seemed to dry and shrink in some parts of the mold, especially the grooved region, while other parts were still receiving material and well before the main body had approached a solid condition. With the casting "locked" in these quick-to-dry regions, uniform shrinkage could not occur and the overall cast invariably cracked in the center. Because the center had not solidified, the mold could not be removed to allow movement.

Variations in solids content in the slip was investigated but did not correct the problem. Highsolids-content slip for reduced shrinkage (the shrinkage problem is discussed below) would immediately solidify in the fins of the grooved face and choke off the flow required for filling the back of the mold. Low-solids-content slip worked better but resulted in problems during drying as discussed below.

Multiple variations of the mold designs to eliminate the problem were also attempted but none were totally successful. The best design was the last, a seven-part mold with imbedded air channels whereby the channels could be pressurized and the cast piece released from the mold by pressure transmitted through the porous plaster. A summary of the five major steps taken in the development of this approach is given in Table 4.1.

The freezing problem observed during filling of the mold might be completely resolved with a change in mold design. However, given the complexity of the mold as it stands (seven pieces), it is doubtful any more features could be added without compromising the ability to keep the mold closed against the hydrostatic pressure applied during casting.

Similar to injection molding, slip casting also had the problem of the material not "knitting." During drying, the shrinkage caused cracks before the piece was removed from the mold. Lowsolids-content slips were the worst, with so much shrinkage that the grooves would break off before 
Table 4.1. CMI Casting Attempts

\begin{tabular}{|c|c|c|}
\hline Attempt & System. $w / 0^{(a)}$ & Results \\
\hline Prototype & $82 \mathrm{w} / 0$ & $\begin{array}{l}\text { Swelled. Cracked to } \\
\text { pieces. }\end{array}$ \\
\hline 1 & $82 w / 0$ & $\begin{array}{l}\text { Many } 0.25 \text {-in. cracks. } \\
\text { Pullouts. }\end{array}$ \\
\hline 2 & $\begin{array}{l}80 \mathrm{w} / 0 . \text { No PVB. } \\
4825 \mathrm{cp}, 12 \mathrm{~h} .\end{array}$ & $\begin{array}{l}\text { Less apparent shrink } \\
\text { cracks. More demolding } \\
\text { cracking. }\end{array}$ \\
\hline 3 & 13 h. New mold. & $\begin{array}{l}\text { Cracked into three } \\
\text { pieces. Due to } \\
\text { demolding and at flow } \\
\text { lines. }\end{array}$ \\
\hline 4 & Upright. 5psi head. & $\begin{array}{l}\text { Sealed over fill giving } \\
\text { hollow. Two narrow } \\
\text { main cracks. }\end{array}$ \\
\hline 5 & $\begin{array}{l}\text { Porous release } \\
\text { tubing. }\end{array}$ & $\begin{array}{l}\text { CM-IV. Excellent } \\
\text { release. One shrinkage } \\
\text { crack in center. Hollow } \\
\text { cast due to leak. }\end{array}$ \\
\hline
\end{tabular}
Recommendations
Add fill hose. Eliminate flow lines.
Lower viscosity by $w / 0$. Extend demold time.

New mold. Same system.

Configure upright for better handling and flow.

Old configuration. Lower shrinkage.

Less shrinkage.

(a) Weight percent of solids, balance toluol.

the mass was dry enough to remove from the mold. However, even high-solids-content slips were problematic and cracked before removal. It is unclear how this problem could be remedied other than through the development of new molding materials with better consolidating efficiency. Unfortunately, identification of such materials is not straightforward.

Due to the above problems, CM-IV was completely cracked when it was removed from the mold prior to sintering. Despite this failure, the anode was still fired, albeit in two pieces, to see what a final sintered piece looked like. Clearly, additional development work is required to make, not only a suitable fired anode, but also an acceptable green piece separate from the effects of sintering. According to the Rutgers Center, the piece had very low chances of casting successfully because of the large differences of cross-section, i.e., the dimensions of the grooves relative to the rest of the piece.

\subsection{Post-Fabrication Analysis}

This section covers the results of analyses performed at PNL on the advanced design anode CM-IV fabricated by CMI using slip casting. 


\subsubsection{Appearance}

As shown in Figure 4.1, the overall shape of anode CM-IV was similar to the target specifications. In particular, the grooves were close to the required length and width. Slight overall differences were due to errors in shrinkage estimation that could easily be corrected in subsequent attempts. The top of the piece, however, had a 1-in.-deep and 4-in.-diameter depression (Figure 4.1c) that was not in the original drawing. Also, similar to CM-I, no ridges and hole were molded in the top surface for the electrical connector rod. The reason for the differences is similar to the rationale regarding CM-I that was discussed in Section 2.2. The desired shape was very complex, so certain shortcuts were taken in the processing to obtain the "best" piece in this first series of attempts. A summary of the pertinent dimensions of CM-IV and how they compared with the target specifications is given in Table 4.2.

Anode CM-IV was $32 \mathrm{lbs}$. It was lighter than CM-I because of its smaller overall height and because of the large recess in the center of the top of the piece.

Anode CM-IV suffered from a number of flaws. First, it was cracked in two pieces. As indicated in Section 4.2, the cracking occurred during the molding process. In addition to the large crack, there were also numerous smaller cracks throughout the anode (Figure 4.1d). Some of these appeared to be aligned in planes roughly parallel to the top surface. It is believed that these cracks formed during molding similar to the large crack, although their final appearance may have been modified during sintering. The shape of CM-IV was also slightly distorted in some places and appeared to be "dirtier" than the other CMI grooved anodes, i.e., it left more residue when rubbed against another surface.

Unlike CM-I, CM-IV showed virtually no metal bleed-out. Only two metal beads were found on the surface and these were silver colored. The anode also had a more silver appearance on cut surfaces, unlike $\mathrm{CM}-\mathrm{I}$ which was more $\mathrm{Cu}$-colored. In these respects, $\mathrm{CM}-\mathrm{IV}$ was more like $\mathrm{CM}$-III and the PNL anodes. This suggests that the metal phase in CM-IV contained more Ni than in CM-I, and this was corroborated by EDS analysis as indicated below.

Table 4.2. Key Dimensions of CM-IV

\begin{tabular}{|c|c|c|c|}
\hline Description & Symbol & CM-IV, in. & Target, in \\
\hline Top Surface (Square) & TS & $7.88 \times 7.75$ & $8 \times 8$ \\
\hline Total Height & TH & 3.5 & 4.5 \\
\hline Groove-to-Lip & GL & 3 & 1.25 \\
\hline Groove Height or (Depth) & GH & 1.5 & 1.5 \\
\hline Groove Separation & GS & 1.5 & 1.5 \\
\hline Overhanging Lip Thickness & LT & 2.4 & 0.75 \\
\hline
\end{tabular}




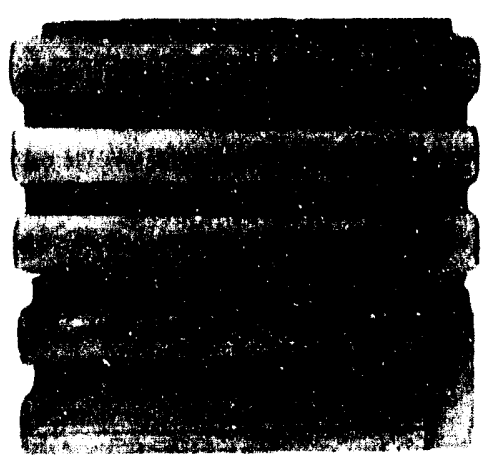

(a)

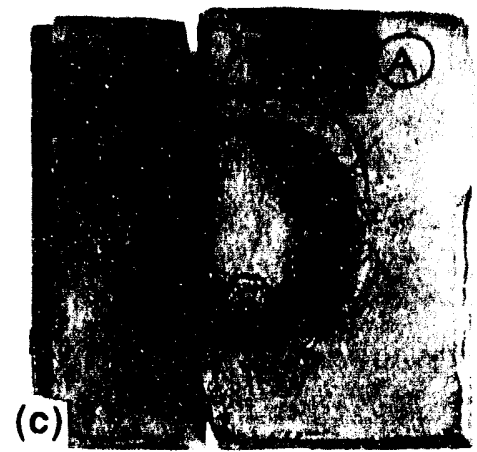

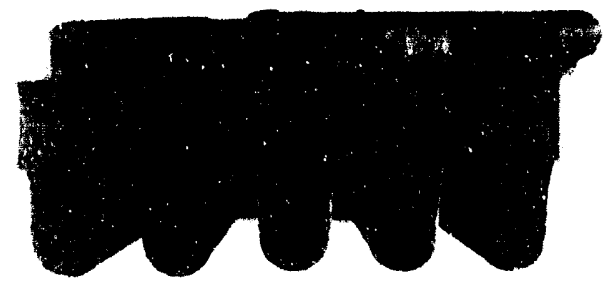

(b)

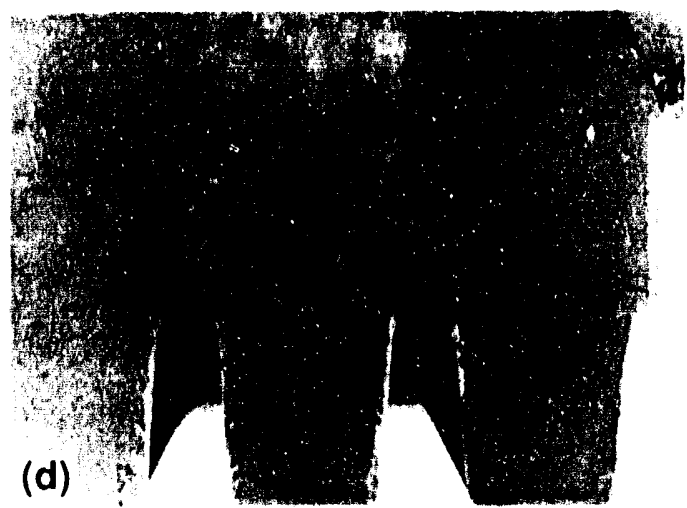

Figure 4.1. Views of CM-IV: a) Bottom Surface Showing Grooves; b) Side View Showing Grooves; c) Top View Showing Depression; and d) Close-Up Side View Showing Cracks

\subsubsection{Density}

The average density of three samples removed from CM-IV was $5.87 \pm 0.10 \mathrm{gcm}^{-3}$. This density is between that measured for CM-I (lower) and CM-III (higher). Based on the arguments given in Sections 2.0 and 3.0, this would suggest that, relative to the other two anode materials, CMIV contains an intermediate amount of porosity and/or has a metal phase with an intermediate $\mathrm{Ni}$ content. As indicated in Section 4.3.3, both of these situations appear to be the case for CM-IV.

\subsubsection{Microstructure and Composition}

Similar to CM-I, two, 1-in.-diameter core sections were removed from CM-IV. These core sections were subsequently cut into a total of eight samples, three of which (the perfect cylinders) were used for the density measurements. One of the remaining pieces was used for microscopic and compositional analysis.

As shown in Figure 4.2, the microstructure of CM-IV appeared to be more evenly distributed than in CM-I, but also appeared to show a significant amount of fine porosity (about $4-\mu \mathrm{m}$-diameter 


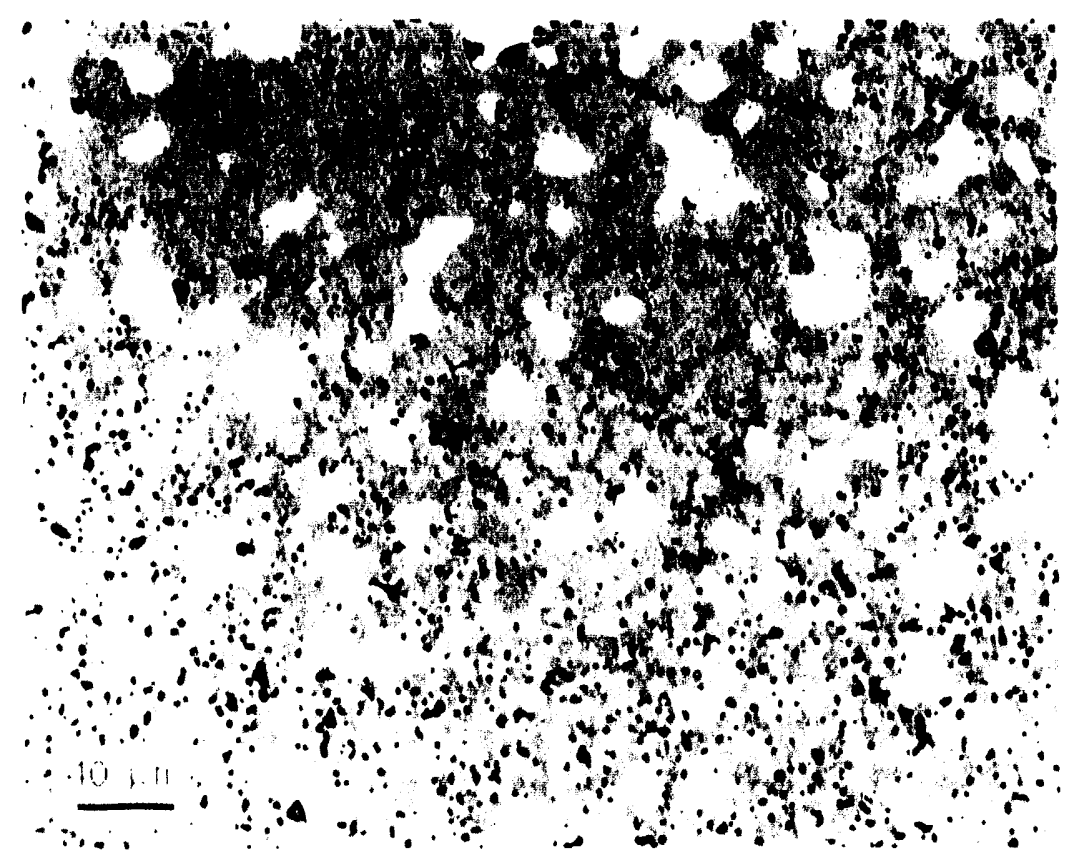

Figure 4.2. Optica! Micrograph of Sample from ('M-IV Showing Typical Microstructure

pores). The material also had some large "holes" (about 0.5 -mm diameter) as shown in figure 4.3 . It is believed that the small pores formed due to incomplete sintering, while the large holes resulted from gas trapped in the slip during molding. The former problem could be corrected by more complete sintering while the latter should be alleviated by more thorough degassing of the slip.

Simular to ('M-I, and unlike ( $M-I I I$ and the PNI. anodes, the alloy phase in ('M-IV was bordered by both oxide phases (Figure 4.4). It also had the more "granular" appear of the microstructure of ( $\mathrm{M}-\mathrm{I}$ as compared to that of $\mathrm{CM}$-III and the PNL anodes. The alloy phase in ( $\mathrm{M}$ IV was about $84 \mathrm{a} / 0$ ('u and $1.3 \mathrm{a} / \mathrm{O} \mathrm{Ni}$ which is richer in Ni than $\mathrm{CM}-1$, but poorer in Ni than (M-III (significantly poorer) and the PNL anodes (slightly poorer). These results are consistent with the density measurements. (M-IV appears to be "intermediate" in microstructure, composition, and properties between ( $\mathrm{M}-\mathrm{I}$ and $(\mathrm{M}$-III. The lower level of alloying of the metal phase with $\mathrm{Ni}$ probably resulted from the smaller amount of residual bunder in CM-IV during sintering. The binder level was sufficient to alloy the metal phase slightly but not enough to result in the desired microstructure and density. Since the PNL anodes exhibited a range of alloy phase compositions with only slightly higher amounts of $\mathrm{Ni}(1.5-25 \mathrm{a} /())$, it may be that only slightly more alloying in ( $\mathrm{M}-\mathrm{IV}$ may have resulted in a more favorable microstructure. However, since the high isostatic pressures used in the fabrication of the PNL anodes was also believed to have an important impact on the composition and microstructure, this conclusion is made with some reservation. Additional experimentation is clearly needed to identify the best route for optimizing the microstructure of the slip casted anodes. 


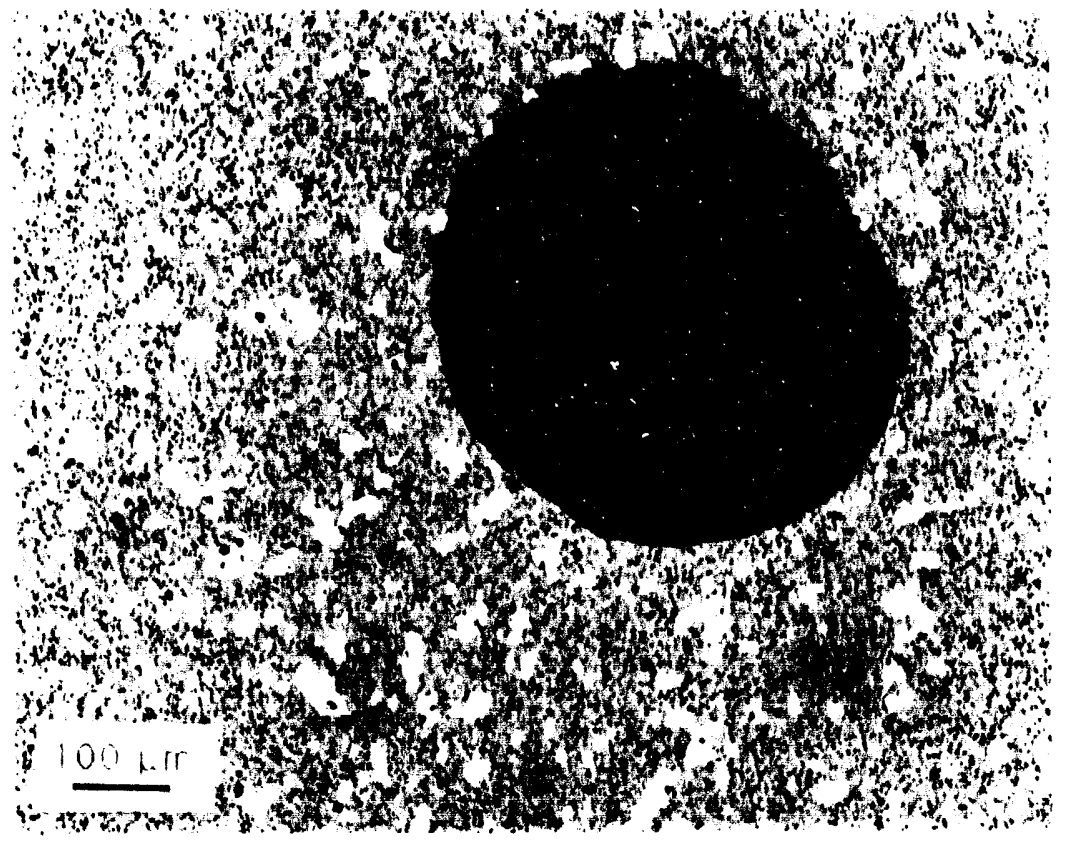

Figure 4.3. Optical Micrograph of Sample from CM-IV Showing Hole

\subsection{Conclusions}

The results for CM-IV indicate that this anode is somewhat intermediate between CM-I and CMIV in its physical and microstructural properties. The amount of binder left in the material prior to sintering must have been significant, although not as great as with CM-III or typically with the PNL anodes, to reduce some of the Ni-containing oxides and thus alloy the $\mathrm{Cu}$ metal with $\mathrm{Ni}$. This reduction occurred despite attempts to remove much of the binder before sintering. It is likely that the culprit was the oily component which, almost certainly, had a higher vaporization temperature than the toluol. As it turns out, the presence of some residual binder appears to be favorable for developing the desired microstructure. Consequently, some strategy for keeping more organic in the piece prior to sintering might be in order, although too much organic would inevitably cause cracking as it vaporized. One possibility is that slightly more of a "heavier" organic (i.e. oily component) could be used, although this change in procedure could have side effects that wotild, in turn, have to be addressed.

The small amount of metal bleed-out for CM-IV is also consistent with the greater amount of $\mathrm{Ni}$ alloying with the Cu metal. However, the microstructure was still "granular" as in CM-I. It appears that somewhat more $\mathrm{Ni}$ in the metal phase was required to attain precisely the same microstructure as 
in CM-III and the PNL anodes. One way to achieve this microstructure may have been through the presence of more residual binder. This conclusion is not exclusive, however, since the high consolidation pressure in the case of the PNL anodes was also a factor in attaining the desired microstructure.
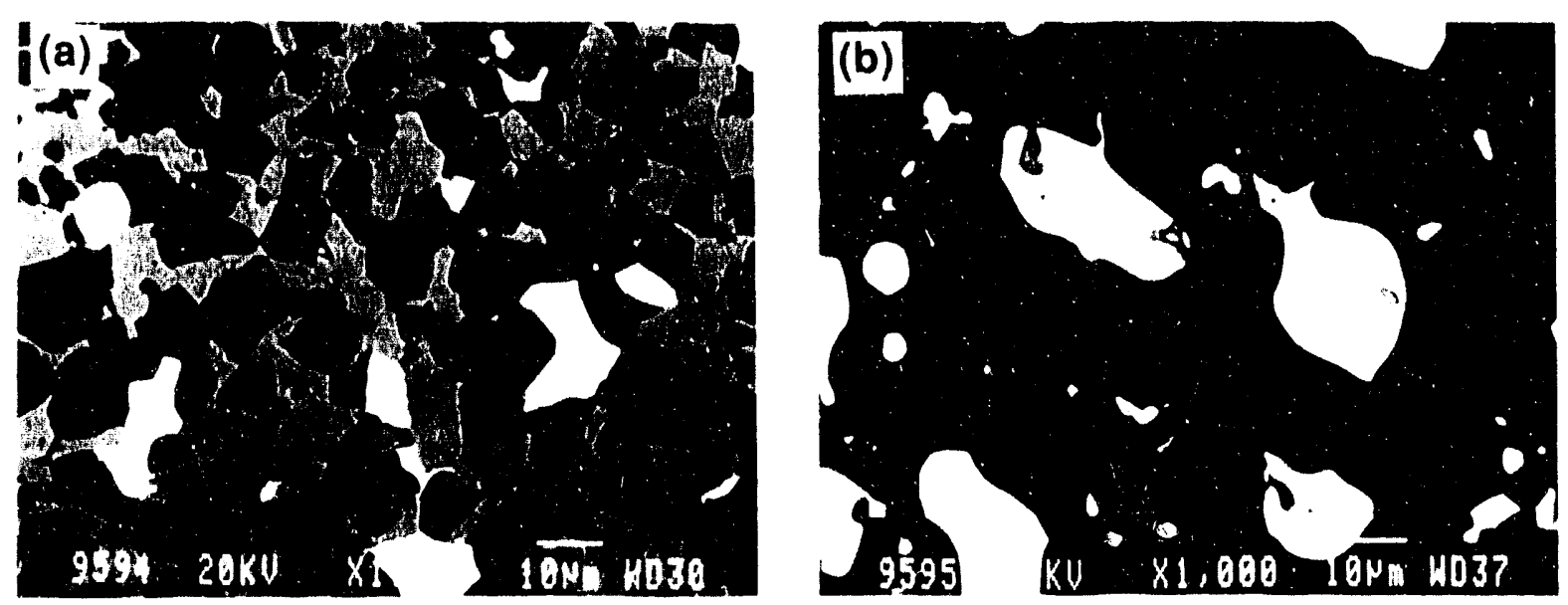

Figure 4.4. SEM Micrographs of: a) Sample from CM-IV; and b) Sample from PNL Anode 


\subsection{Conclusions}

\subsection{Overall Comparison of the Approaches}

Of the three approaches used to make the advanced design anodes, isostatic pressing gave an anode with the best dimensional characteristics. It was also the most straightforward approach to use, despite considerable complexities in mold design. Success with this approach was, of course, facilitated by the experience gained by PNL over the course of the Inert Electrodes Program and the know-how of CMI gained partly from making the pilot cell anodes. The other two approaches, injection molding and slip casting, showed severe shortcomings in this preliminary work; but, admittedly, were not evaluated on the same basis as isostatic pressing. This preliminary study was, in fact, the first known application of these latter two approaches to the cermet material.

One of the interesting results of this work was that, if one overlooks the occurrence of major flaws such as cracks and holes, the anode material with an "intrinsic" microstructure most similar to that of anodes made previously at PNL was made using injection molding. Surprisingly, isostatic pressing did not yield an optimal microstructure in this study. The reason for this may be fortuitous and have to do with the binder residuals in the material during sintering, and will certainly be affected by higher consolidation pressures which are recommended for any future fabrication work using isostatic pressing. Nevertheless, the similarity between the injection molded microstructure and that of PNL anodes was striking (Figure 3.2), as was the similarity between the composition of its phases. A summary of the comparison of the composition of the three phases of the cermet material made by each of the three methods, along with data from a previously-made PNL anode and a pilot cell anode (Windisch et al. 1992a), is given in Figure 5.1. With the exception of a slight surplus of $\mathrm{Ni}$ in the metal phase, the injection molded material is very similar in composition to that of the PNL anode.
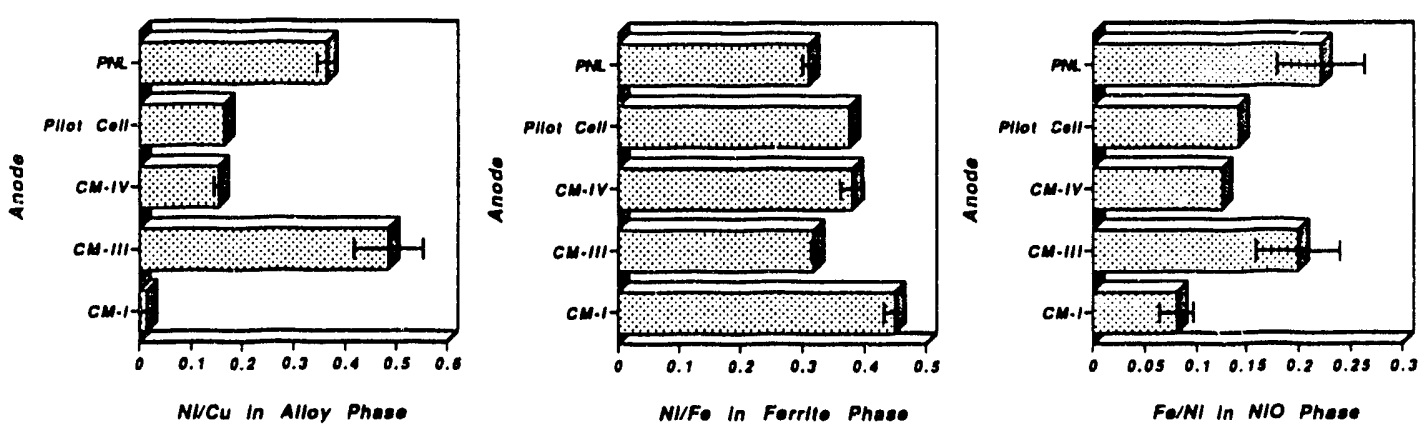

Figure 5.1. Comparison of Compositions of the Three Phases in the Cermet Material from Various Anode Sources 


\subsection{Recommendations}

The overall conclusions and recommendations from this preliminary work to evaluate three methods for the fabrication of large cermet anodes with the advanced design for aluminum smelting are as follows:

- Isostatic pressing is the approach that seems closest to implementation for making cermet anodes. The dimensions of the anode made by this method were reasonably close to the target specifications. However, addiuonal developn.ent wort is still required before the approach can be used reliably. Most importanily, it needs to produce large anodes with composition and microstructure more similar to anodes made previously at PNL. How to achieve this microstructure in large pieces is not trivial and is a separate issue from making the anodes with the desired, i.e., grooved, shape. Solution to this problem may be as simple as using higher consolidation pressure, or as complicated as controlling binder residuals and rates of binder burn-out. In any case, this issue needs to be addressed prior to any future reduction cell testing of the material to avoid ambiguities in the interpretation of the results such as those encountered in previous pilot cell testing (Windisch et al. 1992a). Other problems that need to be solved are the elimination of the crust that forms on the anodes during sinterirg and the redesign of the mold to give the desired structur'; to the top of the anode for the electrical connector.

- Injection molding in not immediately appropriate for making cermet anodes because of problems associated with the large amount of binder in this process. Making this approach work for the cermet anodes would seem to involve either redesigning the anode so that smaller pieces could be made or developing a more suitable binder for the cermet material. The first alternative is unlikely given other concerns about reduction cell operation; while the second possibility would, altiost certainly, involve extensive additional research and development. While not infeasible, the likelihood of success using this approach is considered low in the short run.

- Slip casting was used to make a lüge grooved anode, but there were serious deficiencies in the material. Most of these seemed to arise from the molding step, and, similar to the injection molding approach, involve the vehicle for making the slip. Consequently, this approach cannot be recommended in the short run either. Significant research and development to understand the role of the binder and optimize its composition is still required.

- Significant work still remains to be done on the electrical connection scheme regardless of the fabrication approach used. The best approach in previous work at PNL involved using a "graded" core in the cermet anode (Strachan et al. 1989), although attempts to employ this core in large (pilnt cell) anodes were not successful (Windisch et al. 1992a). Cracks tended to form near the core material during sintering. Consequently, it is anticipated that, even if the grooved anodes are made to speciñication, additional work will be required to resolve the electrical coinection problems. 
- It is strongly recommended that no additional large-scale reduction cell testing be performed on the cermet anodes until the anodes can be made with properties and microstructure essentially identical to anodes tested previously at PNL and Alcoa Laboratories. The purpose of these large-scale tests will probably be to evaluate the cermet anode material as it was originally developed. Experience from the pilot cell test (Windisch et al. 1992a) indicates that dissimilarities between the material being tested and that developed previously make the interpretation of true performance very difficult. 


\subsection{References}

Billehaug, K., and H. A. Oye. 1981. "Inert Anodes for Aluminum Electrolysis in Hall-Heroult Cells (I)." Aluminum, Vol. 57, pp. 146-150.

Edirisinghe, M. J., and J. R. G. Evans. 1986. "Review: Fabrication of Engineering Ceramics Injection Moulding. I. Materials Section." Int. J. High Technology Ceramics, Vol. 2, pp. 1-31.

Evans, J. W., and R. Shekhar. 1990a. Physical Modeling of Bubble Phenomena. Electrolyte Flow and Mass Transfer in Simulated Advanced Hall Cells. DOE/ID-10281, University of California, Berkeley, California.

Evans, J. W., and R. Shekhar. 1990b. Physical Modeling of Bubble Phenomena, Electrolyte Flow and Mass Transfer in Simulated Advanced Hall Cells - Addendum. DOE/ID-10281-Add., University of California, Berkeley, California.

Segal, D. 1989. Chemical Synthesis of Advanced Ceramic Materials. Cambridge University Press, Cambridge, England.

Strachan, D. M., O. H. Koski, S. C. Marschman, C. H. Schilling, C. F. Windisch Jr., B. B. Brenden, N. C. Davis, and P. E. Hart. 1988. Fiscal Year 1987 Annual Report for the Inert Electrodes Program. PNL-6746, Pacific Northwest Laboratory, Richland, Washington.

Strachan, D. M., S. C. Marschman, N. C. Davis, J. R. Friley, and C. H. Schilling. 1989. Fiscal Year 1988 Annual Report for the Inert Electrodes Program. PNL-7106, Pacific Northwest Laboratory, Richland, Washington.

Strachan, D. M., C. F. Windisch Jr., O. H. Koski, L. G. Morgan, R. D. Pederson, N. E. Richards, and A. T. Tabereaux. 1990. Results from Electrolysis Test of a Prototype Inert Anode. PNL-7345, Pacific Northwest Laboratory, Richland, Washington.

Tarcy, G. P. 1986. "Corrosion and Passivation of Cermet Inert Anodes in Cryolite-Type Electrolytes." Light Metals 1986, The Minerals, Metals and Materials Society, Warrendale Pennsylvania, pp. 309-320.

Weyand, J. D., D. H. DeYoung, S. P. Ray, G. P. Tarcy, and F. W. Baker. 1986. Inert Anodes for Aluminum Smelting: Final Technical Report for the Period 1980 September 29 - 1985 September 30. DOE-CONS-40158-20, Alcoa Laboratories, Alcoa Center, Pennsylvania.

Windisch, C. F., Jr., and N. D. Stice. 1991. Final Report on the Characterization of the Film on Inert Anodes. PNL-7589, Pacific Northwest Laboratory, Richland, Washington. 
Windisch, C. F., Jr., D. M. Strachan, C. H. Henager Jr., E. N. Greenwell, and T. R. Alcorn. 1992a. Results from a Pilot Cell Test of Cermet Anodes. PNL-8269, Pacific Northwest Laboratory, Richland, Washington.

Windisch, C. F., Jr., B. B. Brenden, O. H. Koski, and R. E. Williford. 1992b. Final Report on the PNL Program to Develop an Alumina Sensor. PNL-8296, Pacific Northwest Laboratory, Richland, Washington. 


\section{Distribution}

No. of

Copies

\section{OFFSITE}

M. J. McMonigle

U.S. Department of Energy

Office of Industrial Programs

Forrestal Building

Washington, DC 20585

P. H. Salmon-Cox

U.S. Department of Energy

Office of Industrial Programs

Forrestal Building

Washington, DC 20585

12 DOE Office of Scientific and

Technical Information

T. Alcorn

Manufacturing Technology

Laboratory

Reynolds Metals Co.

3326 East 2nd Street

Muscle Shoals, AL 35661-1258

C. Anderson

Columbia Aluminum Co.

85 John Day Dam Road

Goldendale, WA 98620

J. V. Anderson

WCVE3

EG\&G Idaho, Inc.

Idaho Falls, ID 83415

D. Auburg

Bonneville Power Administration

P.O. Box 3621, PDX 97208

Portland, OR 97208
No. of

Copies

F. W. Baker

Ceramics Division

Alcoa Laboratories

Alcoa Center, PA 15069

M. Baltzell

Eastalco Aluminum Company

Alumax, Inc.

5601 Manor Woods

Frederick, MD 21701

J. A. Barclay

U.S. Bureau of Mines

2401 "E" Street N.W.

Washington, DC 20241

H. Robert Baumgartner

Ceramics Division

Alcoa Laboratories

Alcoa Center, PA 15069

T. R. Beck

Electrochemical Technology Corp.

1601 Dexter Avenue

Seattle, WA 98109

S. Berwagan

Bonneville Power Administration

P.O. Box $3621 \mathrm{~K}$

Portland, OR 97208

T. M. Besmann

Metals and Ceramics Division

Oak Ridge National Laboratory

P.O. Box X, Bldg. 4515

Oak Ridge, TN 37831-6063

Distr. 1 
No. of

Copies

K. A. Blakely

President

Advanced Refractory

Technologies, Inc.

699 Hertel Ave.

Buffalo, NY 14207

M. H. Blenk

Du Pont

P.O. Box 787

Niagara Falls, NY 14302

L. G. Boxall

Martin Marietta Laboratories

1450 South Rolling

Baltimore, MD 21227

J. Bracher

Kaiser Aluminum and Chemical Corp.

825 N.E. Multnomah St.,

Suite 960

Portland, OR 97232-2150

J. J. Brown, Jr.

Materials Engineering

Virginia Polytechnic Institute

Blacksburg, VA 24061

\section{A. Budner}

Bonneville Power Administration

P.O. Box 3621--EPA

Portland, OR 97208

\section{A. J. Caputo}

Development Division

Oak Ridge Y-12 Plant

Building 9202 MS-8095

Oak Ridge, TN 37831-8095
No. of

Copies

N. Clark

Bonneville Power Administration Industrial Conservation

P.O. Box 3621

Portland, OR 97208

A. Cooke

Martin Marietta Laboratories

1450 South Rolling

Baltimore, MD 21227

J. A. Coppola

Standard Oil Engineered Materials Company

P.O. Box 156

Niagara Falls, NY 14302

R. Curtis

Materials Development

Corporation

81 Hicks Avenue

Medford, MA 02155

J. V. Day

Kaiser Aluminum and Chemical Corp.

E 2111 Hawthorne Road

Mead, WA 99021

D. H. DeYoung

Alcoa Technical Center

Alcoa Center, PA 15069

T. Dwonch

Snake River District BPA

101 W. Poplar

Walla Walla, WA 99362

Distr. 2 
No. of

Copies

R. Engdahl

Deposits and Composites, Inc.

318 Victory Drive

Herndon, VA 22070

J. F. Elliott

MIT

Room 4-138

77 Massachusetts Avenue

Cambridge, MA 02139

D. Emerson

Kaiser Aluminum/DTC

East 2107 Hawthorne Rd.

Mead, WA 99021

B. G. Epstein

A. D. Little, Inc.

955 Lenfant Plaza SW 4200

Washington, DC 20024-2119

J. W. Evans

University of California

Dept of Matl. Sci. and Mineral Eng.

Berkeley, CA 94720

D. A. Figgins

ARCO Petroleum Products Co.

P.O. Box 61004

Anaheim, CA 92803-6104

P. Foster

Alcoa Laboratories

P.O. Box 772

New Kensington, PA 15068

J. Gee

Great Lakes Research Corp

P.O. Box 1031

Elizabethton, TN 37643
No. of

Copies

T. Gilligan

Eltech Systems Corp.

625 East Street

Fairport Harbor, OH 44077

W. M. Goldberger

Superior Graphite Co.

120 S. Riverside Plaza

Chicago, IL 60606

J. Goodwell

Center for Metals Production

Mellon Institute

4400 Fifth Avenue

Pittsburgh, PA 15213

J. Gregg

Eltech Research Corporation 625 East Street

Fairport Harbor, OH 44077

J. A. S. Green

Martin Marietta Laboratories

1450 South Rolling

Baltimore, MD 21227

C. Griffin

Ceramatec Inc.

2425 S. 900 West

Salt Lake City, UT 84119

L. I. Grindstaff

Great Lakes Research Corp.

P.O. Box 1031

Elizabethton, TN 37643

J. Haggerty

MIT

Building 12, Room 009

77 Massachusetts Avenue

Cambridge, MA 02139

Distr. 3 
No. of

Copies

I. L. Harry

Electric Power Research

Institute

P.O. Box 10412

Palo Alto, CA 94303

W. E. Haupin

2820 7th Street Road

Lower Burrell, PA 15068

R. Hill

Union Carbide Corp.

P.O. Box 94637

Cleveland, $\mathrm{OH} 44101$

H. F. Hillegass

Alcoa Wenatchee Works

P.O. Box 221

Wenatchee, WA 98807

D. G. Howitt

College of Engineering

University of California, Davis

Davis, CA 95616

F. R. Huettig

Ceramic Magnetics, Inc.

16 Law Drive

Fairfield, NJ 07004

G. R. Hyde

U.S. Bureau of Mines

2401 "E" Street N.W.

Washington, DC 20241

S. C. Jacobs

Primary Processing

Aluminum Company of America

Alcoa Technical Center

Alcoa Center, PA 15069
No. of

Copies

S. H. Jan

Tennessee Valley Authority

R\&D Division - MR 3A

Chattanooga, TN 37401

N. Jarrett

149 Jefferson Avenue

New Kinsington, PA 15068

J. Johnson

Intalco Aluminum Company

P.O. Box 937

Ferndale, WA 98248

L. Joo

Great Lakes Research Corp.

P.O. Box 1031

Elizabethton, TN 37643

M. Karmous

Oregon State Department of Energy

625 Marion Street, N.E.

Salem, OR 97310

R. Keller

RD 3 Roundtop Road

Export, PA 15632

C. W. Koerr

The Stackpole Corporation

Cermag Division

201 Stackpole Street

St. Marys, PA 15847

K. Krupinski

Aristech Research

1000 Tech Center Dr.

Monroeville, PA 15146

G. Y. Lai

Cabot Corporation

P.O. Box 9013

Kokomo, IN 46902-9013

Disti. 4 
No. of

Copies

J. E. Lane

Ceramic Research and

Development Center

Westinghouse Electric Corp.

1310 Beulah Road

Pittsburgh, PA 15235

S. K. Lau

Standard Oil Engineered Materials Company

Niagara Falls R\&D Center

P.O. Box 832

Niagara Falls, NY 14302

J. J. Leddy

Dow Chemical U.S.A.

1776 Building

Midland, MI 48640

W. W. Liang

Gas Research Institute

8600 West Bryne Mawr Avenue

Chicago, IL 60631

W. H. Link

Columbia Aluminum Corp.

85 John Day Dam Road

Goldendale, WA 98620

S. Loftness

Washington State Energy Office

400 E. Union

Olympia, WA 98504

W. Long

Building B815

Dow Chemical

Freeport, TX 77541

A. G. Longmuir

Kaiser Aluminum and Chemical Corp.

P.O. Box 877

Pleasanton, CA 94566
No. of

Copies

R. A. Lowden

Metals and Ceramics Division

Oak Ridge National Laboratory

P.O. Box X, Bldg, 4515

Oak Ridge, TN 37831-6063

W. N. Maclay

Koppers Company, Inc.

1005 William Pitt Way

Pittsburgh, PA 15238-1336

J. C. McCloskey

Ten Mile River Associates

296 Mt. Hope Street

North Attleboro, MA 02760

G. Mamantov

University of Tennessee

Knoxville, TN 97996

S. C. Manaktala

Manager of Technology

Reduction Division

Kaiser Aluminum and Chemical

Corp.

300 Lakeside Drive

Oakland, CA 94643

V. H. Markant

Du Pont

P.O. Box 787

Niagara Falls, NY 14302

C. J. McMinn

Manufacturing Technology

Laboratory

Reynolds Metals Co.

3326 East 2nd Street

Muscle Shoals, AL 35661-1258

Distr. 5 
No. of Copies

C. H. McMurtry Standard Oil Engineered Materials Company Niagara Falls R\&D Center P.O. Box 832

Niagara Falls, NY 14302

M. A. Mitnick

Avco Specialty Materials

Subsidiary of Textron Inc.

2 Industrial Avenue

Lowell, MA 01851

H. Mortensen

R. Palika

Cercom, Inc.

P.O. Box 70

Vista, CA 92083

P. Ness

Washington State Dept of Trade and Economic Development

2001 6th Avenue $\# 2600$

Seattle, WA 98121-2522

C. L. Nikias

30010 Via Borica

Rancho Palos Verdes, CA 90274

J. R. Payne

Kaiser Aluminum and Chemical

Corp.

P.O. Box 877

Pleasanton, CA 94566

T. Payne

Columbia Falls Aluminum Co.

Columbia Falls, MT

W. Pebley

Oregon Freeze Dry Corp.

525 25th Avenue SW

P.O. Box 1048

Albany, OR 97321
No. of

Copies

R. D. Peterson

Manufacturing Technology

Laboratory

Reynolds Metals Co.

3326 East 2nd Street

Muscle Shoals, AL 35661-1258

T. R. Pritchett

Kaiser Aluminum and Chemical Corp.

P.O. Box 877

Pleasanton, CA 94566

W. W. Pritsky

Aluminum Association

900 19th St. N.W.

Washington, DC 20006

S. P. Ray

Alcoa Technical Center

Alcoa Center, PA 15069

Resource Center

Washington State Dept of Trade and Economic Development

2001 6th Avenue $\$ 2700$

Seattle, WA 98121-2522

J. F. Rhodes

Advanced Composite Materials

Corp.

1525 S. Buncomb Rd.

Greer, SC 29651

N. E. Richards

Manufacturing Technology

Laboratory

Reynolds Metals Co.

3326 East 2nd Street

Muscle Shoals, AL 35661-1258

Distr. 6 
No. of

Copies

\section{J. J. Ritter}

Ceramics Division

National Bureau of Standards

Gaithersburg, MD 20899

R. C. Rohwedder

3028 Ohio Street Longview, WAD.

R. Sadoway MIT Room 8-109

77 Massachusetts Avenue

Cambridge, MA 02139

W. Scott

Department of Materials

Science \& Engineering

Wilcox Hall FB-10

University of Washington

Seattle, WA 98195

D. R. Secrist

Great Lakes Research Corp.

P.O. Box 1031

Elizabethton, TN 37643

A. B. Shah

Noranda Aluminum, Inc.

P.O. Box 70

New Madras, MO 36869

Brian Spector

Pace Consultants

4848 Loop Central Drive

Houston, TX 77081

F. W. Spillers

Dow Chemical U.S.A.

B-1210 Building

Freeport, TX 77541

R. M. Spriggs

Office of the Director

Center for Advanced

Ceramic Technology

Alfred University

Alfred, NY 14802
No. of

Copies

D. V. Stewart

Manufacturing Technology

Laboratory

Reynolds Metals Co.

3326 East 2nd St.

Muscle Shoals, AL 35661-1258

D. Strahan

Reynolds Metals Company

P.O. Box 27003

Richmond, VA 23261

A. T. Tabereaux

Manufacturing Technology

Laboratory

Reynolds Metals Co.

3326 East 2nd Street

Muscle Shoals, AL 35661-1258

G. P. Tarcy

Aluminum Company of America

Alcoa Technical Center

Alcoa Center, PA 15069

P. Thaure

Alumax, Inc.

5655 Peachtree Parkway

Norcross, GA 30092

W. H. Thielbahr

Conservative Technology

Division

DOE-Idaho Operations Office

785 DOE Place

Idaho Falls, ID 83402

S. Thomson

General Manager

Klickitat PUD

1313 S. Columbus

Goldendale, WA 98620

Distr. 7 
No. of

Copies

R. Unger Merner Research

P.O. Box 248

Ridgewood, NJ 07451

L. VanDillan

Ceramic Magnetics, Inc.

Fairfield, NJ 07004

A. Vinnard

Bonneville Power

Administration (KWI)

P.O. Box 3621

Portland, OR 97208

T. Von Muller-KWI

Bonneville Power Administration

P.O. Box 3621

Portland, OR 97208

D. H. Weinblatt

AIMCOR

One Parkway North

Deerfield, IL 60015

J. D. Weyand

EG\&G Idaho, Inc.

Idaho Falls, ID 83415

B. Wilcox

Northwest Aluminum Co.

$3313 \mathrm{~W}$. Second St.

The Dalles, OR 97058

C. B. Wilson

Dow Chemical U.S.A.

Texas Operations

B-101 Building

Freeport, TX 77541
No. of

Copies

\section{FOREIGN}

D. Brodie

Comalco Ltd.

55 Collins St.

Melbourne,

AUSTRALIA

H. Connor

Group Licensing Controller

Johnson Matthey, plc

New Garden House

78 Hatton Garden

London EC1N 8JP

ENGLAND

T. Kjar

Comalco Ltd.

55 Collins St.

Melbourne,

AUSTRALIA

E. W. Dewing

Alcan International

P.O. Box 8400

Kingston, Ontario

CANADA K7L 4Z4

D. N. MacMillan

Alcan International

C.P. 1250

Jonquieve, Quebec

CANADA G7S 4K8

A. Oye

Institute of Inorganic

Chemistry

Norwegian Institute of

Technology

University of Trondheim

N-7034 Trondheim-NTH, NORWAY

Distr. 8 
No. of

Copies

J. Thonstad

Laboratories of Industrial Electrochemistry

Norwegian Institute of Technology

University of Trondheim N-7034 Trondheim-NTH, NORWAY

K. O. Vee ASV Ardal Verk N-5875 Ardalstargen, NORWAY

\section{E. Frazer}

CSIRO Australia

Division of Mineral Products 339 Williamstown Road

P.O. Box 124

Port Melbourne, Vic 3207
No. of

Copies

\section{ONSITE}

DOE Richland Field Office

D. R. Segna

23 Pacific Northwest Laboratory

M. Clement

D. K. Hilliard

G. L. McVay

N. L. Moore

L. G. Morgan

D. M. Strachan

R. W. Westerman

C. F. Windisch (10)

Publishing Coordination

Technical Report Files (5)

Distr. 9 

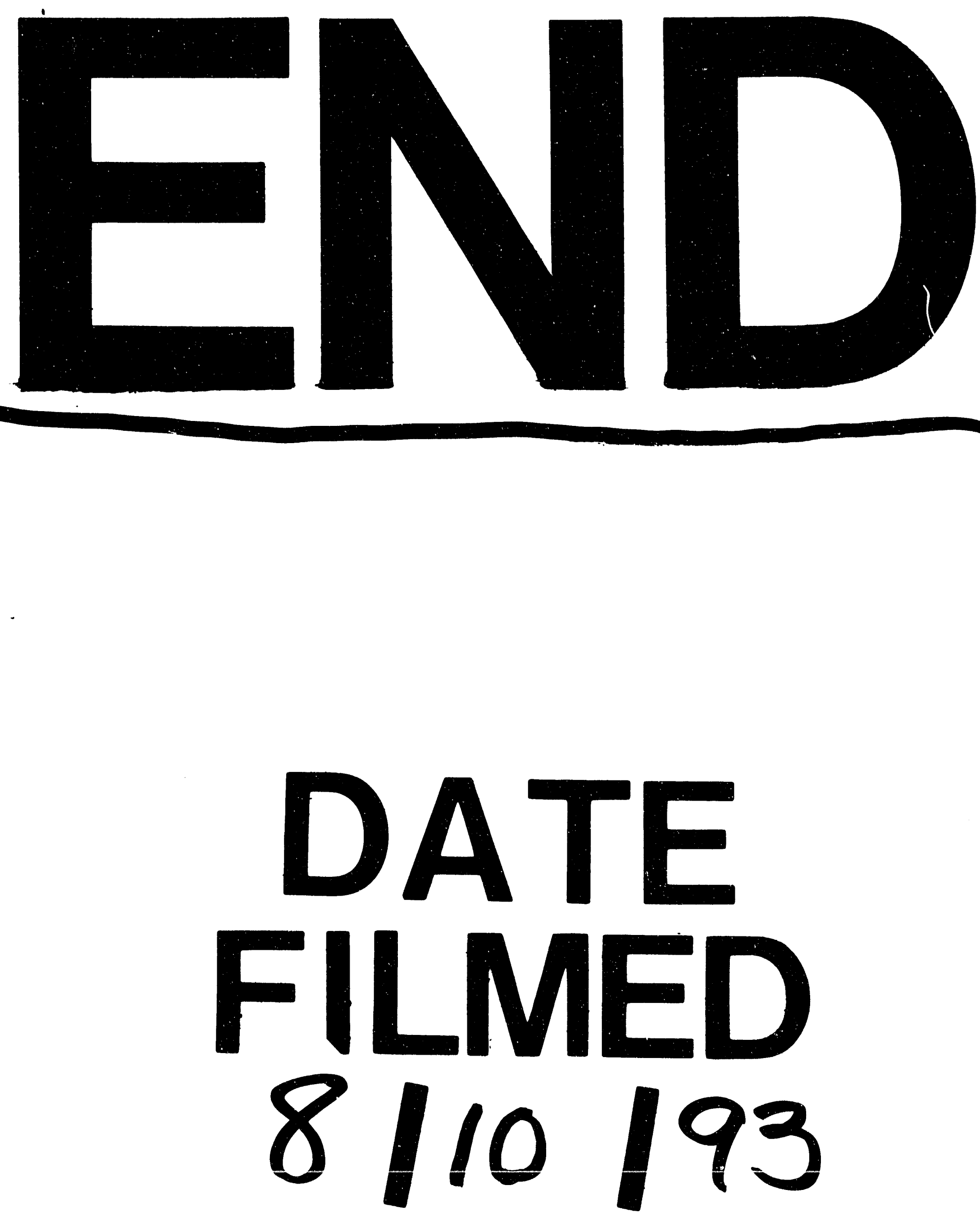